\title{
The 1914 Taisho eruption of Sakurajima volcano: stratigraphy and dynamics of the largest explosive event in Japan during the twentieth century
}

\author{
A. Todde $^{1,2} \cdot$ R. Cioni ${ }^{1}$ (ID $\cdot$ M. Pistolesi ${ }^{1} \cdot$ N. Geshi ${ }^{3} \cdot$ C. Bonadonna $^{4}$
}

Received: 20 February 2017 / Accepted: 6 September 2017

(C) Springer-Verlag GmbH Germany 2017

\begin{abstract}
The 1914 Taisho eruption of Sakurijima volcano was Japan's highest intensity and magnitude eruption of the twentieth century. After a 35-year period of quiescence, the volcano suddenly rewoke a few days before the eruption, when earthquakes began to be felt on Sakurajima Island. The eruption began on January 12, 1914, from two fissures located on opposite sides of the volcano, and was characterized by a complex time evolution and changes in eruptive styles. The eruption began with a subPlinian explosive phase in which two convective columns rose from the two fissures. Both plumes were sustained for at least 2 days. This resulted in deposition of a widely dispersed tephra sequence. After this phase, the eruption evolved to a final, waning phase, shifting toward effusive activity that lasted until April 1914. During the first weeks, effusive activity was also accompanied by ash emission. The complex sequence of events, characterized by
\end{abstract}

Editorial responsibility: J. Fierstein

Electronic supplementary material The online version of this article (https://doi.org/10.1007/s00445-017-1154-4) contains supplementary material, which is available to authorized users.

R. Cioni

raffaello.cioni@unifi.it

1 Dipartimento di Scienze della Terra, Università di Firenze, Florence, Italy

2 Volcanic Risk Solutions, Institute of Agriculture and Environment, Massey University, Palmerston North, New Zealand

3 Geological Survey of Japan, National Institute of Advanced Industrial Science and Technology, Tsukuba, Japan

4 Département des Sciences de la Terre, Université de Genève, Geneva, Switzerland contemporaneous explosive and effusive activity, is typical of several recently observed mid-intensity eruptions, such as during the 2011 eruption of Cordón Caulle, Chile. The stratigraphic sequence of the eruptive deposits from the Taisho eruption comprises alternating coarse-to-fine lapilli beds with ash beds dispersed toward the ESE and SE. These deposits can be subdivided into three lapilli-bearing units (Units T1, T2 and T3, which correspond to the subPlinian phase) and one ashbearing unit (Unit T4, which corresponds to the final ash venting, accompanying the first day/weeks of lava flow activity). Grain size analyses from each unit reveal a marked polymodal distribution generally described by the sum of two or three Gaussian subpopulations. Both the modes and the relative amounts of the coarse subpopulations vary with distance from vent, with those of the fine subpopulation remaining nearly constant. Within the vertical sequence, component analysis shows a progressive increase in lithic fragments, suggesting that conduit enlargement continued until the final stages of the eruption. The estimated volume of the tephra deposit of the subPlinian phase of the eruption is $0.33 \pm 0.11 \mathrm{~km}^{3}$ (dense rock equivalent (DRE) volume $=0.09 \pm 0.03 \mathrm{~km}^{3}$ ). The height of the eruption column was also assessed by using four different isopleth maps compiled based on different strategies for the characterization of the largest clasts. The maximum height attained by the eruption column is estimated at $15.0 \pm 1.2 \mathrm{~km}$ above the vent, resulting in a maximum mass discharge rate of $3.6 \pm 1.2 \times 10^{7} \mathrm{~kg} \mathrm{~s}^{-1}$ (calculated taking into account the strong effect of wind advection). Finally, different classification schemes were applied to classify the eruption, which generally straddles the fields between Plinian and subPlinian.

Keywords Taisho eruption · Sakurajima volcano · Stratigraphy · Plinian · subPlinian 


\section{Introduction}

Mid- to large-intensity explosive eruptions are commonly fed by intermediate-to-silicic magmas (Walker, 1981; Cioni et al. 2015). They are characterized by the quasi-steady, hours-long, high-velocity discharge of a multiphase mixture of gas, solid, and liquid particles into the atmosphere (Wilson et al. 1980; Woods 1995; Gonnermann and Manga 2013). These form a buoyant, vertically ascending column that can reach heights of tens of kilometers (Carey and Bursik 2015). Such eruptions may include a sustained phase, but they also typically consist of a complex succession of volcanic pulses with sustained, quasi-steady convective plumes that alternate and overlap with pulsatory explosions of different styles, intensities, and dynamics (Cioni et al. 2015). They also involve a phase of lava extrusion, as a flow or dome, meaning that this class of eruption is a complex, mixed, explosive-effusive type (Rittmann 1962; Bonadonna et al. 2016).

Although the frequency of occurrence of mid-intensity, VEI 3-4 eruptions is high, with global recurrence times ranging between months to a few years (Simkin and Siebert 2000; Pyle 2015; Mason et al. 2004), their eruptive dynamics still remain poorly understood, mainly due to the complex pattern of different eruptive styles associated with these events (Cioni et al., 2015; Bonadonna et al., 2016). The two recent eruptions of Chaitén and Cordón Caulle (Chile), which occurred in 2008 and 2011, respectively (Alfano et al. 2011; Pistolesi et al., 2015), offered the chance to study in detail explosive eruptions of this mixed, complex type. Both of these eruptions provided important case-types for this kind of activity and confirmed that investigation of such events can be particularly valuable for assessing the different hazards associated with such a large spectrum of eruptive styles.

The purpose of this study is to provide a high-resolution stratigraphy of the tephra sequence emplaced during the midintensity, mixed explosive-effusive eruption that occurred at Sakurajima in 1914. The primary aim of this stratigraphic reconstruction is to gain further insights into the dynamics and physical volcanology of the Taisho eruption so as to better understand the eruptive behavior of major (Plinian to subPlinian) events at Sakurajima. Such events have occurred with relatively high frequency during the history of Sakurajima, where there have been at least 14 such events over the last 10 ka (Kudo and Hoshizumi 2006; Kobayashi et al. 2013). In addition, because the area around the volcano is densely populated, we provide a dataset of the main physical parameters that characterize the subPlinian explosive phase of the eruption, which is crucial for the hazard assessment related to a large-scale eruptive event at Sakurajima. These data are used in the companion paper of Biass et al. (2017) to achieve just such an assessment and to set up a blueprint as to how such assessments should proceed at Sakurajima-type systems. The study of this eruption allowed to define a case-type for mixed (explosive-effusive) style of subPlinian eruptions, not very well defined in the volcanological literature, although quite common (Bonadonna et al. 2016).

More than 30 stratigraphic sections were studied from around the volcano and out through the nearby Osumi Province. Around 70 samples were collected to investigate the main sedimentological and physical properties of the tephra deposits. Analyses focused on the characterization of the grain size distribution of tephra deposits and its variation within the dispersal area, as a key to understand sedimentological processes and eruptive style. Componentry and density estimates were performed at the reference section to assess the nature of the deposits and to investigate the internal variability of the tephra sequence. Field observations and stratigraphic reconstruction allowed estimation of several eruptive parameters that allow characterization of the eruptive styles, which were then compared with other published data and historical accounts.

\section{Geological background}

Sakurajima (Cherry Island in English) volcano is located inside Kagoshima Bay (southern Kyushu, Japan), on the southern rim of the Aira caldera (Fig. 1), which formed following a catastrophic ignimbrite eruption that occurred ca. 29,000 BP (Machida 2002; Kobayashi et al. 2013; Geshi and Miyabuchi 2016). Aira caldera occupies the northern end of Kagoshima Bay and is part of the Kagoshima graben, a large tectonic structure which hosts several late Quaternary calderas (Nagaoka 1988). Sakurajima volcano started erupting $26,000 \mathrm{BP}$ on the southern rim of the caldera (Kobayashi et al. 2013) and is composed of two overlapping stratovolcanoes, namely Kitadake and Minamidake (Fig. 1a). Initially an island, the volcano is now connected to the Osumi Peninsula by a narrow isthmus formed by a lava flow that was erupted during the 1914 eruption.

Based on tephra stratigraphy and radiocarbon dating, the eruption history of Sakurajima has been dived into four stages: Older Kitadake, Younger Kitadake, Older Minamidake, and Younger Minamidake. During Younger Minamidake stage, at least four large-scale eruptions occurred (eruptions P4 to P1), each named after the Japanese era in which they happened: Tenpyo-Hoji (764-766 AD), Bunmei (1471-1476 AD), Anei (1779-1782 AD), and Taisho (1914-1915 AD) (Omori 1916; Kobayashi et al. 2013). Historical accounts of the former two eruptions are fragmented, while more detailed records exist for the Anei eruption (Imura 1998). Several documents, eyewitness accounts, and even geophysical data are available for the Taisho eruption (Koto 1916; Omori 1916; Yasui et al. 2006). The last three historical eruptions occurred along different fissure systems on two opposite sides of the volcano and developed through a similar sequence of eruptive events. Eruptions 


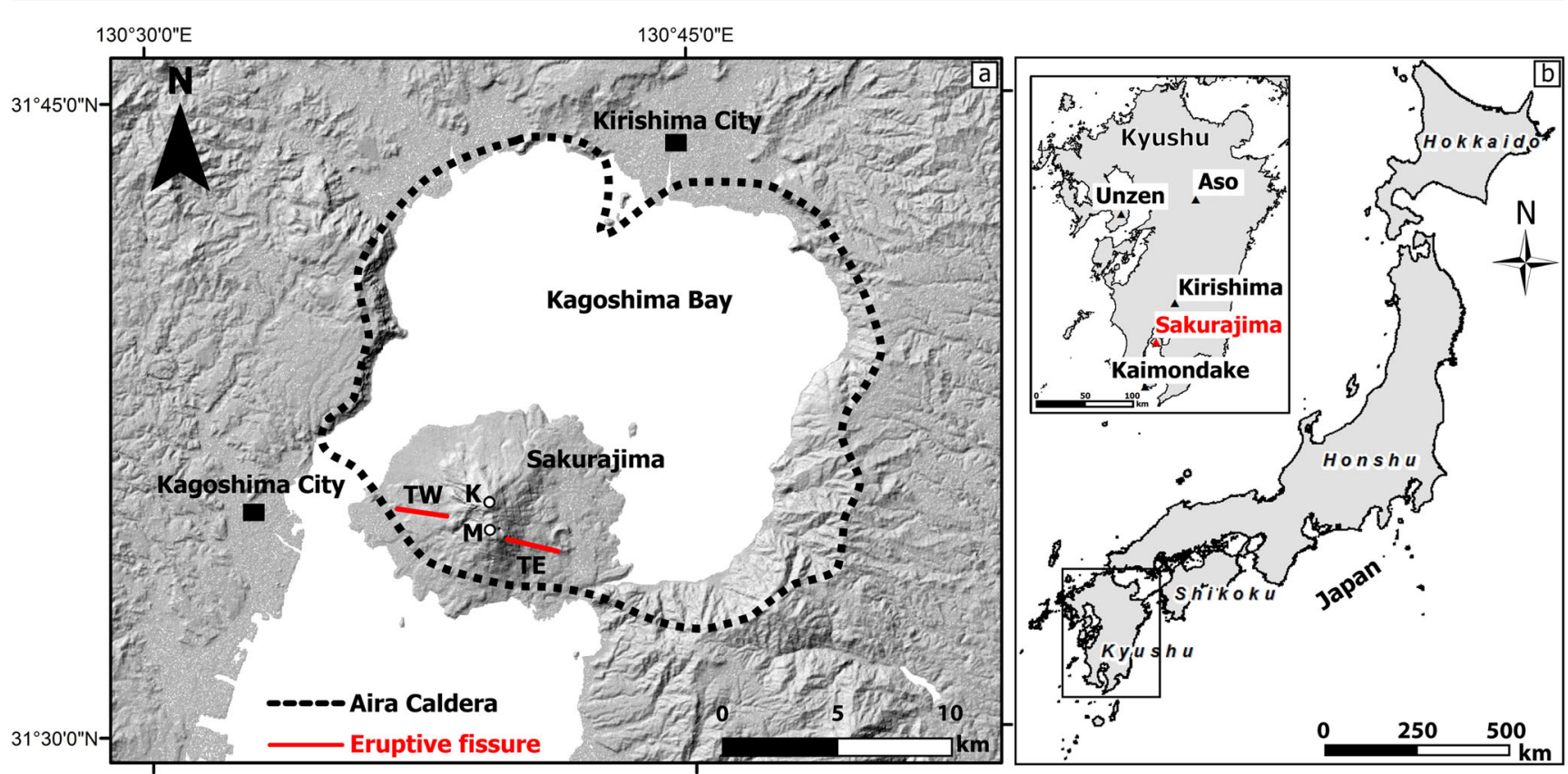

Fig. 1 a Shaded relief map of Aira Caldera and Sakurajima volcano. Border of Aira caldera (black dashed line) is drawn following Kobayashi et al. (2013). The position of the eruptive fissures $(T W=$ Taisho West fissure, $T E=$ Taisho Est fissure) is traced following vents

typically began with a subplinian or Plinian-style activity, followed by a prolonged phase of lava effusion that lasted for several months or years to emplace between 0.5 to $1.5 \mathrm{~km}^{3}$ dense rock equivalent (DRE) volume (Ishihara et al. 1981).

The chemical composition of the erupted products from Sakurajima shows a progressive decrease of $\mathrm{SiO}_{2}$ content over the last six centuries (Takahashi et al. 2013). During the Bunmei eruption, mostly dacitic (66 to $68 \mathrm{wt} \% \mathrm{SiO}_{2}$ ) lava was erupted. During the Anei eruption, the $\mathrm{SiO}_{2}$ content of the lavas decreased to $63-65 \mathrm{wt} \%$, while during the most recent Taisho eruption, olivine-bearing pyroxene andesitic lavas were erupted (59 to $62 \mathrm{wt} \% \mathrm{SiO}_{2}$ ). Currently, the volcano is characterized by persistent Vulcanian activity that erupts andesitic-todacitic tephra (63.5-69.7 wt\% $\mathrm{SiO}_{2}$; Miwa et al. 2013).

\section{Chronology of the Taisho eruption (1914-1915 AD)}

The Taisho eruption was the largest eruption in Japan during the twentieth century. Here, the chronology is described based on the two seminal works of Omori (1916) and Koto (1916) and the eruption summaries given by Yasui et al. (2006, 2007). Seismological observations are available thanks to a Gray-Milne-Ewing seismometer installed at the Kagoshima Weather Station since 1888. Tromometers also recorded precursory activity from locations in Nagasaki, Osaka, and Tokyo (respectively 148, 560, and $959 \mathrm{~km}$ from Sakurajima), albeit incompletely. alignments reported in Omori (1916). Letters $K$ and $M$ indicate Kitadake and Minamidake central craters, respectively. b Location of Sakurajima volcano in southern Kyushu (Japan)

After a period of quiescence, probably lasting at least since 1879 (Koto 1916), Sakurajima suddenly reawakened during the early morning of January 11, 1914 when earthquakes started to be felt on the island (Omori 1916). As many as 418 events were recorded from Kagoshima between about 3:40 am on January 11 and 10 am on January 12, when the eruption began (all times reported in this work refer to local time, UTC + 9). Intensity of the seismic activity probably increased during the $15 \mathrm{~h}$ preceding the eruption, when most of the recorded events became clearly perceivable. Abe (1979) estimated a magnitude of $\sim$ M5 for 11 of these events. During the first hours of January 11, a landslide from the summit crater descended the western slopes of the volcano (Koto 1916). Drastic changes in the subsurface hydrological system were also reported in the period immediately preceding the eruption, as evidenced by variations observed in the discharge of hot and cold springs all around the volcano. On the morning of January 12 , hot water began to copiously issue from several points along the southern coast of the island. At the same time, while new cold-water springs formed on the opposite side of the island, water in some wells had risen by at least $1 \mathrm{~m}$. The frequency of seismic events increased on January 11, and several audible rumblings and landslides also occurred on the island; by $9 \mathrm{am}$, the roads were already damaged in several places around Sakurajima Island.

The eruption began around 10 am on January 12, with the first eruption column issuing from a vent on the western flank of the volcano, $450 \mathrm{~m}$ above sea level (a.s.l.) along a WNWESE trending fissure (TW in Fig. 1a). After about $10 \mathrm{~min}$, a 
second column began to ascend from another vent $400 \mathrm{~m}$ a.s.l. along a second fissure on the eastern flank of the volcano (TE in Fig. 1a). The two plumes had already ascended to a height of more than 5-8 km by 11 am (Yasui et al. 2006), and explosive activity was reported to have been much more powerful on the eastern flank than the western flank (Omori 1916). Local seismicity suddenly decreased after the eruption onset, but at 6:29 pm on January 12, a M7.1 earthquake (possibly of tectonic origin) struck the area, killing 35 people in Kagoshima City. The epicenter was located about $9 \mathrm{~km} \mathrm{SW}$ of Minamidake peak, with a focal depth of $13 \mathrm{~km}$ (Abe 1979).

The climactic phase of the explosive eruption developed between 11 pm on January 12 and 5 am on January 13, with a peak in intensity occurring around $1 \mathrm{am}$. Small pyroclastic flows were generated mainly from the western vents between the afternoon of the first day and the morning of January 13, possibly during the paroxysmal phase, and locally dispersed in a narrow belt between N73 W and N52 W (Omori 1916); no evidence of this type of activity is given for the eastern sector. The restricted area invaded by these pyroclastic flows suggests they were probably related to minor partial column collapses. By the morning of the January 13, the height of the eruption plume was estimated to be between $10 \mathrm{~km}$ (Omori 1916) and $18 \mathrm{~km}$ (Koto 1916). After $10 \mathrm{am}$, the intensity began to decline. At 2:30 pm, the whole Sakurajima island was described as being enveloped in "white and black smokes" (Omori 1916). Then, at 8:30 pm on January 13, incandescence was observed along the flanks of the volcano, associated to the onset of lava effusion.

As clearly stated in the description of the activity given by Omori (1916), ash mainly issued from the eastern vent(s), and its dispersal was driven by westerly winds. According to Omori (1916), activity at the western vent(s) had a lower intensity, with dispersal mainly restricted to the island. Conversely, Koto (1916) reported stronger activity from the western vent(s), although inspection of available photographic material for the eruption seems to confirm Omori's description. Most of the tephra was dispersed generally eastward; upwind deposition being minor with occasional ash fall in Kagoshima City, where only a few millimeters of ash were deposited during the first 3 days of the eruption. Deposits on the island vary between $4 \mathrm{~m}$ in thickness (close to the east vent) and $20 \mathrm{~cm}$ (on the southern coast), and their distribution clearly indicates coexistence of two main active vents on the eastern and western flanks of the volcano.

Detailed inspection of the available photos reveals that the convective part of the plumes from the two different vents may have mixed together and were rapidly blown eastward by the prevailing winds. Between January 12 and 14, the ash fall progressively reached most of Kyushu, Shikoku, and the western part of Honshu, as far as $1200 \mathrm{~km}$ from vent (this being the region of Sendai and its vicinity). Village offices, tobacco plantations, and local meteorological observatories collected precise data for the time of ash arrival and thickness. From these data, we know that ash fall reached the major cities of Fukuoka at 8:00 am on January 13, Osaka by midnight of January 13, and Tokyo during the early morning of January 14 (Fig. 2). Ash was also described as falling at Ogasawara-jima (Bonin Islands), more than $1000 \mathrm{~km} \mathrm{SE}$ of Kyushu, defining a large area of ash dispersal $\left(\sim 1.5 \times 10^{6} \mathrm{~km}^{2}\right)$. Ash deposition at distal locations was generally preceded by some hours of a "peculiar misty condition, which rendered the atmosphere considerably opaque" (Omori 1916). This condition was probably related to the distal dispersal of very fine ash during the first $13 \mathrm{~h}$ of the eruption, before the onset of the climactic phase. Isochrones for the first tephra fallout across Japan can be used to estimate an average velocity of downwind plume margin extent around $9 \mathrm{~m} \mathrm{~s}^{-1}$ (Fig. 2).

Activity in the days following January 13 was largely minor in intensity. Ash fall was observed within a range of about $200 \mathrm{~km}$ from the volcano until January 19, generally toward the north and south, with a clear shift in dispersal with respect to the first 2 days of the eruption. After January 20, the activity decreased further in intensity, with ash reaching mainly localities within the Kagoshima Prefecture (maximum distance of around $50 \mathrm{~km}$ from the vent). Lava issued from several vents aligned both along the western fissure, where seven effusive vents were located, and the eastern fissure, where eight vents were active. Lava flows from the western fissure began on the evening of January 13 and reached the coast on the morning of January 16 , but by January 25 activity at the western fissure had ceased completely. In the eastern sector, the lava reached the sea probably in the first 2 days (January 15). Effusion from the eastern sector had completely closed the Seto Strait, separating former Kagoshima Island from the Osumi peninsula, by early April 1914, after around 80 days from the beginning of this phase. Blocks were observed still falling from the stagnant front and lateral levees of the lava flow until December 1914. Observations during April 1915 confirmed the end of lava effusion, with the main lava fronts stationary and vapor locally rising from the lava flow field (Omori 1916; Yasui et al. 2007).

Lava effusion was accompanied by minor, discontinuous explosive activity, with intermittent explosions forming ephemeral, low-level ash plumes and launching ballistic blocks typically characterized by breadcrust surfaces. Explosions alternated between the many craters along the two fissures. This activity consisted of explosions accompanied by strong seismic activity and minor detonations, as well as explosions accompanied by loud detonations and lowintensity seismic signals (Omori 1916). While the first type of activity was generally associated with emissions of ash, the second type of explosions resulted from the breakage of the lava plugs forming in the vent. The intensity and frequency of explosions decreased by the end of January, although minor explosions and ash emissions occurred intermittently until 


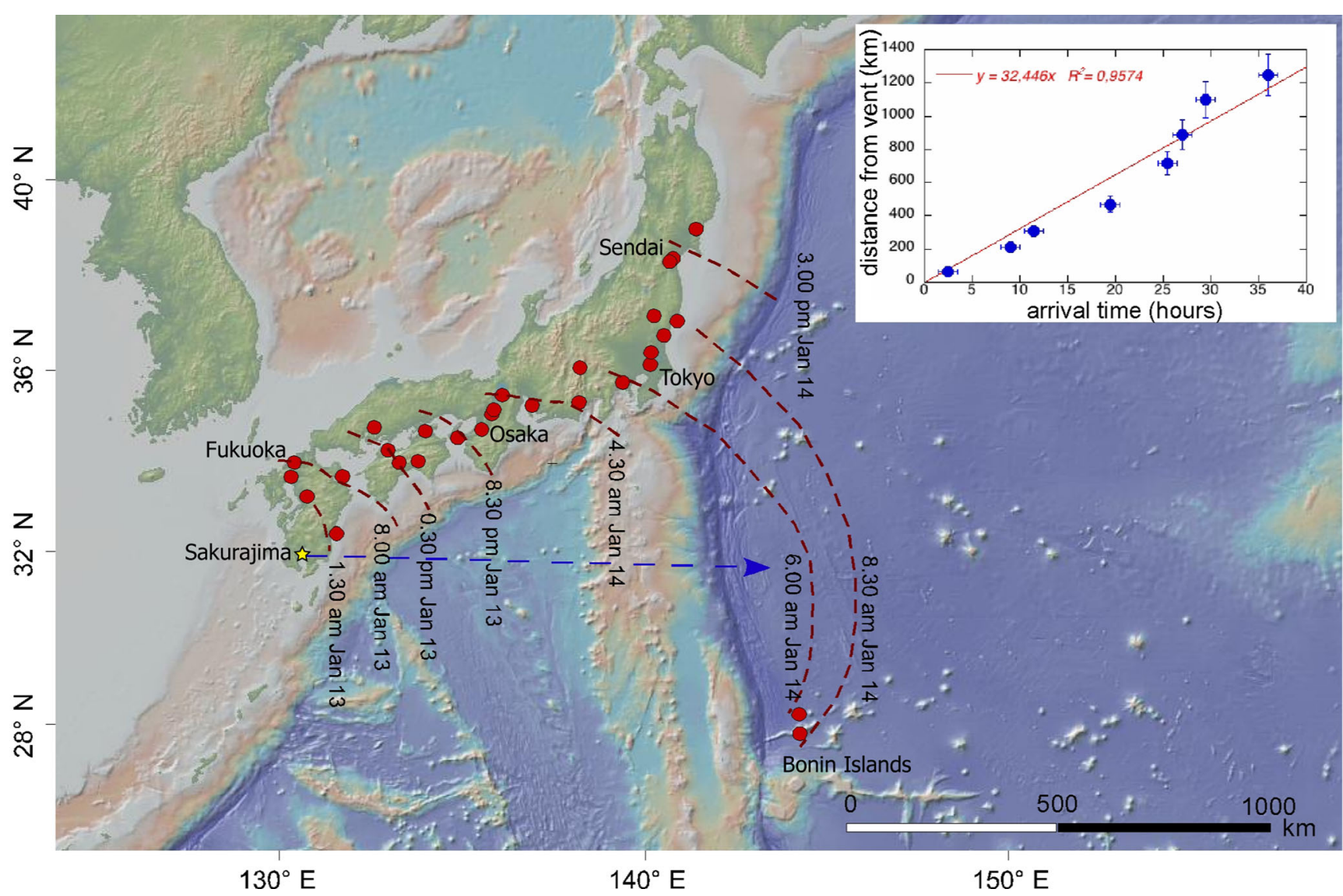

Fig. 2 Isolines of arrival time of ash related to the activity of the first 2 days of the eruption (i.e., subPlinian-Plinian eruption). Ash fall was described in the main islands of Kyushu, Shikoku, and Honshu up to $1200 \mathrm{~km}$ of distance NE from Sakurajima and at Ogasawara-jima

early March 1914, when explosive activity ceased in the western fissure (Yasui et al. 2007). The eruption was thus practically over by the end of April 1914, with only occasional explosions in September 1914 and April-May 1915 from a number of vents along the eastern fissure (Omori 1916), although Koto (1916) reports that one of the vents was still periodically producing minor explosions in October 1915, and seismic tremors were recorded until August 1916. Thanks to a leveling survey conducted by the Japanese Imperial Military in 1891-1895 in south Kyushu, and repeated immediately after the Taisho eruption, significant ground subsidence could be detected (Omori 1916). After the eruption, subsidence occurred concentrically in the northern part of Kagoshima Bay, within the Aira Caldera. Subsidence reached a maximum of about $1 \mathrm{~m}$, and values of $30-50 \mathrm{~cm}$ were observed in Kagoshima City. Present-day uplift of the area has attained levels close to those preceding the 1914 Taisho eruption (Hickey et al. 2016).

The impact of the eruption was reduced by the spontaneous evacuation of some 22,000 inhabitants of the island immediately before the eruption, mainly due to the increasing level of seismicity. A summary of the total number of victims and
(Bonin Islands) more than $1000 \mathrm{~km} \mathrm{SE}$ from the volcano (Omori, 1916). Inset, plot of the distance from vent at which ash was observed vs. ash arrival time; time measurements are not along the main dispersal axis as indicated by the blue dashed line

damages related to the M7.1 earthquake and the Taisho eruption is reported by Koto (1916) who lists 35 fatalities (six on Sakurajima), 23 missing and 127 injured (one on Sakurajima). More than 4500 houses were totally or partially destroyed by lava, pyroclastic flows, and ash, while the earthquake caused the total collapse of approximately 120 buildings in Kagoshima City. More than 2000 horses, cattle, and pigs were killed by the eruption, and agriculture and crops suffered severe damage. An economic loss of more than 4 million Japanese Yen was estimated, related to damage to properties, corresponding to about 4 billion JPY at current values ( 35 million US dollars).

\section{Methods}

In this work, the stratigraphic architecture of the Taisho tephra deposits was investigated at more than 30 sites on and around the volcano in the Osumi Province (Fig. 3). The deposits, often covered by abundant subtropical vegetation, were observed in natural or road cuts and at hand-dug sections. At each site, a detailed stratigraphic section was measured and 


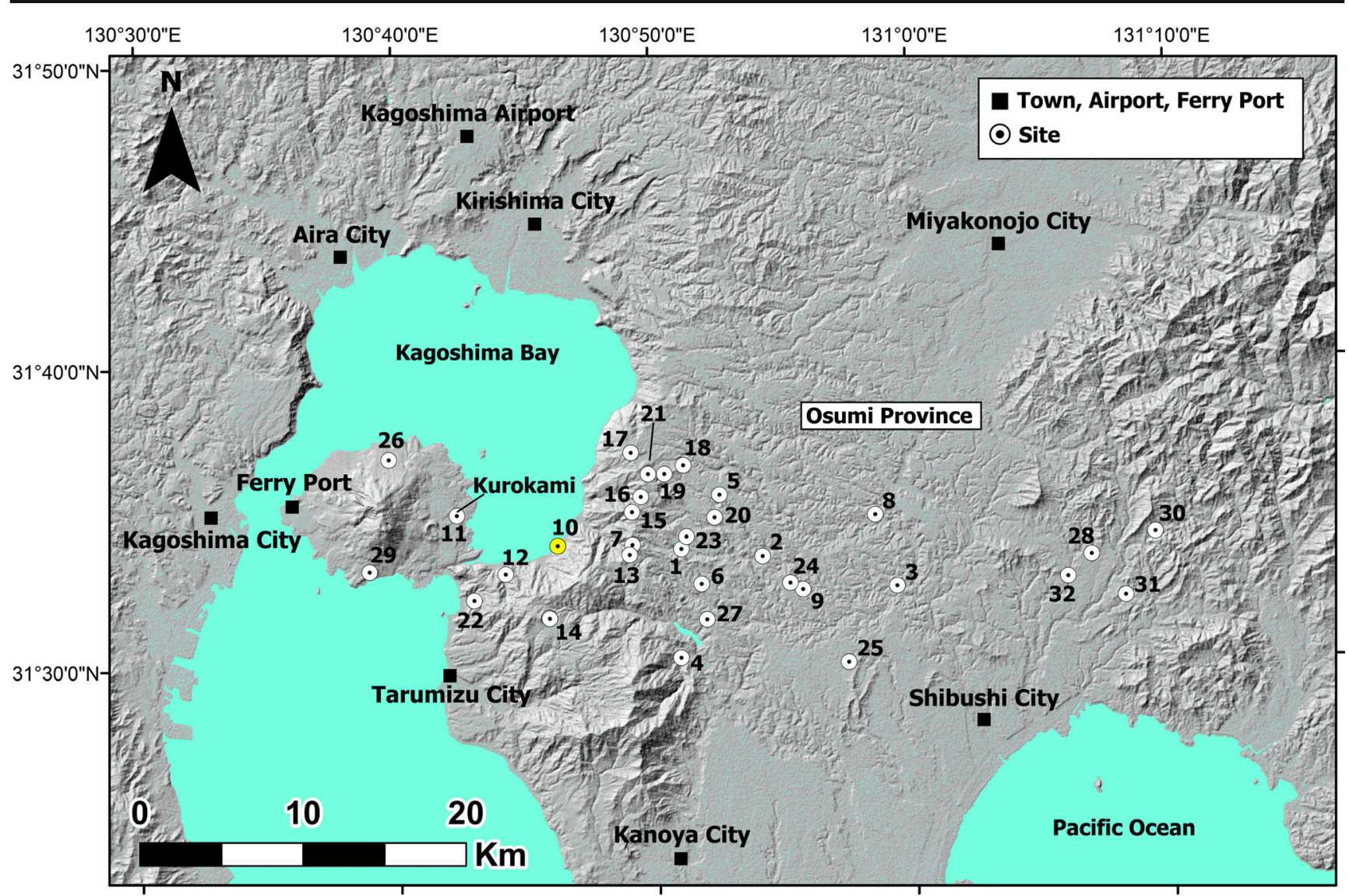

Fig. 3 Shaded relief map showing location and number of stratigraphic sections (reference section in yellow) and the main exposed elements (i.e., Towns, Airport, Ferry Port). Site 11 is located next to the buried Kurokami Shinto shrine

described, and samples were collected from the different units to characterize the main sedimentological and physical properties of the tephra deposits. Thickness was measured at each outcrop, and an isopach map was compiled to calculate the deposit volume of the eruption using exponential, power-law, and Weibull methods (Pyle, 1989; Fierstein and Nathenson, 1992; Bonadonna and Houghton, 2005; Bonadonna and Costa, 2012). The average of the values derived from the three different methods was used as the best estimate for the minimum volume (Bonadonna et al. 2015a). For the Exponential method, two line segments with different slopes were used to describe the different decay rates of deposit thicknesses in proximal and medial-to-distal areas. The proximal limit of integration for the power-law fit is assumed as the maximum thickness at zero distance from the vent (i.e., $4.1 \mathrm{~m}$ ), as it is estimated from the exponential fit (see Bonadonna and Houghton 2005), while the distal integration limit was fixed at values of 100,300 , and $500 \mathrm{~km}$. The power-law coefficient $m$ for the Taisho tephra deposit is 2.6; thus, the method is not very sensitive to the choice of the distal integration limit (Bonadonna and Houghton 2005; Bonadonna et al. 2015a).

Samples collected at each site were dried for at least $24 \mathrm{~h}$ in an oven at $100{ }^{\circ} \mathrm{C}$ and dry sieved down to $\phi=+1$, at $0.5 \phi$ intervals ( $\phi=-\log _{2} D$, with $D$ being the particle diameter in millimeters). To minimize breakage of the largest pumice clasts, the coarser fraction $(-5.5 \phi$ to $-1.5 \phi)$ was sieved by hand, and the fraction between $-1.5 \phi$ and $+1 \phi$ was dry sieved for 5 min with a mechanical shaker. Grain size analyses were performed using the facilities of the Research Institute of Earthquake and Volcano Geology in Tsukuba (Japan), INGV-Pisa (Italy), and the Earth Sciences Department at the University of Florence (Italy). Material finer than $+1 \phi$ was characterized down to $+10 \phi$ using a CILAS 1180 laser diffraction particle sizer (https://www.cilas.com/) at the Department of Earth Sciences of the University of Geneva (Switzerland). Grain size distribution parameters (median and sorting coefficients, $\operatorname{Md} \phi$ and $\sigma \phi$, respectively) were calculated according to Inman (1952). Since all the analyzed samples show a marked polymodality in grain size distribution, data were processed with the SFT software (Wohletz et al. 1989) to deconvolve the distribution into discrete Gaussian subpopulations.

Componentry and clast density analyses were performed on samples from one reference section (site 10 in Fig. 3). Different types of components were separated from the lapilli and very coarse ash fractions $(-5.5 \phi$ to $-0.5 \phi)$ by hand picking under a binocular microscope and then weighed. These fractions make up to $63-74$ wt $\%$ of each sample. Density was measured on 
100 randomly picked juvenile clasts (light-colored pumice; size between $-5 \phi$ and $-3 \phi$ ) from each unit of the reference section in order to describe vertical density variations. Density was measured by hydrostatic weighing on a high-precision electronic balance (precision $=0.0001 \mathrm{~g}$ ). Differences between density measures were considered significant to within $5 \%$ of the measured value. Dried clasts were weighed in air $\left(W_{\text {air }}\right)$, then made impermeable by applying a cellulose acetate coating, and weighed again in air $\left(W_{\text {film }}\right)$. They were then weighed once more immersed in water ( $W_{\text {water }}$ ) of known temperature $\left(T_{\text {water }}\right)$, and clast volume was determined by water displacement using the Archimedes principle. Bulk density of the pumice $\left(\rho_{\text {pumice }}\right)$ was calculated with the relationship $\rho_{\text {pumice }}=W_{\text {air }} /\left(W_{\text {water }} / \rho_{\text {water }}\right), \rho_{\text {water }}$ being the density of water at temperature $T_{\text {water }}$ Bulk vesicularity was then derived from clast density using the equation of Houghton and Wilson (1989), based on a DRE density of $2500 \mathrm{~kg} \mathrm{~m}^{-3}$ obtained for Taisho magma by Nakamura (2006).

A detailed characterization of the largest clast dispersal was completed following the field procedure and sampling strategy of Bonadonna et al. (2013): at each selected site, a horizontal depositional area of $0.5 \mathrm{~m}^{2}$ was excavated and more than 20 clasts were collected. Clast dimensions were then measured with an accuracy of $1 \mathrm{~mm}$ using a caliper and characterized based on the geometric mean of the three main axes. Two different approaches were used for measuring of the three axes:

- Perpendicular dimensions (PD): The axes longest $(L)$, intermediate $(I)$, shortest $(S)$ are taken perpendicularly between each other with the approximation of the minimum ellipsoid (Krumbein 1941; Bonadonna et al. 2013)

- Projection area protocol (PAP): Axes (not necessarily perpendicular) are measured as the largest and smallest dimensions measured on the maximum-area projection ( $L$ and $I$ ) and the smallest dimension $(S)$ measured in the minimum-area projection (Bagheri et al. 2014; Bagheri and Bonadonna 2016). The advantage of the PAP method is that it does not require dimensions to be perpendicular to each other, and, therefore, it is easier to apply, has lower operator-dependent errors, and provides more accurate estimates of particle volume and surface area with respect to other strategies (Bagheri and Bonadonna 2016).

Following Bonadonna et al. (2013), the choice of the largest clasts at a given site (measured according to the two different methods above) was made using (i) the geometric mean of the three axes of the 50th percentile of a 20-clast population ("50th") and (ii) the arithmetic average of the geometric mean of the three axes of the five largest clasts ("G3/5"). The advantage of the PAP method is that it does not require dimensions to be perpendicular to each other, and, therefore, it is easier to apply, has lower operator-dependent errors, and provides more accurate estimates of particle volume and surface area with respect to other strategies (Bagheri and Bonadonna 2016).Combining the results from the two different approaches (PD and PAP) and the two different choices for the selection of the representative measure (50th and G3/5), we obtained four different estimates of the largest clast at each selected site; thus, four isopleth maps were drawn.

Isopleth maps were drawn up and used to constrain maximum column heights and the peak of the mass discharge rates (MDR). To do this, plume height was derived based on the model of Carey and Sparks (1986) using the Matlab® implementation of Biass et al. (2015) that allows application of the Carey and Sparks (1986) method to a large range of particle sizes and densities. MDR was then calculated based both on the model of Mastin et al. (2009) and that of Degruyter and Bonadonna (2012).

\section{Stratigraphy}

The deposits of the Taisho eruption were dispersed eastward from Sakurajima volcano and have been recognized up to a distance of about $40 \mathrm{~km}$ (Fig. 3). The stratigraphic sequence comprises alternating coarse-to-fine lapilli and ash beds, formed by highly vesicular, light-toned pumice, and by minor, low-to-moderately vesicular, finer-grained dark pumice. Based on distinctive lithological and sedimentological properties (grain size, size grading, stratification, sorting, and color), deposits were subdivided into four lithostratigraphic units: Units T1, T2, T3, and T4. Each unit is formed by two or more beds, which mainly differ in terms of grain size and textural features of the deposit. Units T1 to T3 were especially prominent in the most proximal sections along the dispersal axis (sections 10 and 11, Fig. 3), and a detailed description and sampling of these units was completed at the reference section 10 (Figs. 3 and 4b), located $9 \mathrm{~km}$ east from the eastern vents. Unit T4 could be only in some sections of the southeastern sector (sections 4, 14, 22, 25, 27; Fig. 3). Units T1, T2, and T3 consist of lapilli-bearing beds (Md $\phi$ from -4.1 to 1 ; average $\mathrm{Md} \phi=-1.25$ ), whereas Unit T4 is made up of a centimeter- to decimeter-thick fine ash layer (Md $\phi$ from 2.6 to 4.6; average $\operatorname{Md} \phi=3.1$; Fig. 4). Unit $\mathrm{T} 1$ generally lies directly on a centimeter- to decimeter-thick dark gray soil mixed with ash and scattered fine lapilli-sized pumice clasts, below which Anei (or Anei and Bunmei) eruption pumice-bearing deposits are often found. Stratigraphic correlations between the Taisho tephra units were carried out in proximal and medial areas (Fig. 5). We use the terms proximal, medial, and distal to refer to (1) outcrops on the lower slopes of the volcano within a radius of $5 \mathrm{~km}$ from the present central craters, (2) to outcrops between 5 and $30 \mathrm{~km}$ from vent (Osumi Province), and (3) to distances $>30 \mathrm{~km}$, respectively. In addition, as our field data 


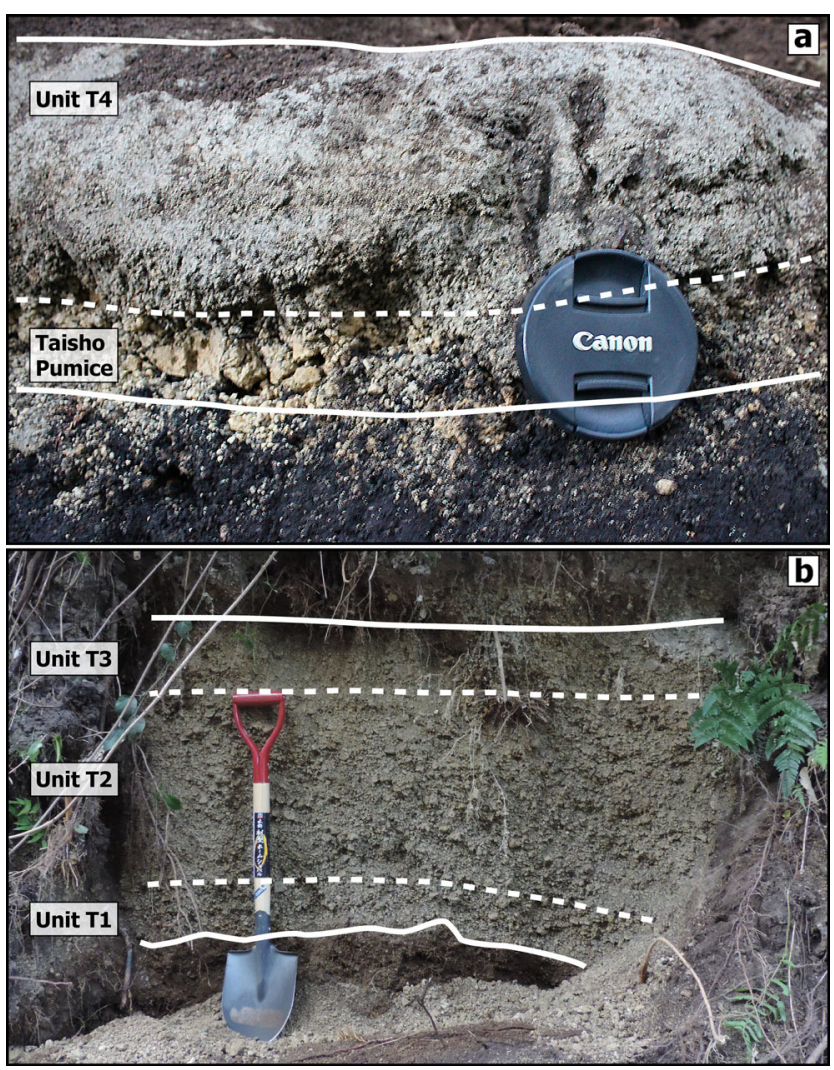

Fig. 4 a Zoom on Unit T4 at key section 14, in the southeastern sector of Taisho eruption, overlaying a lapilli-bearing layer corresponding to T1T2-T3. b Photo of Taisho reference section 10, located along the main dispersal axis, $9 \mathrm{~km}$ east from eastern vents

agree with the description of a more intense explosive activity occurring along the eastern fissure given by Omori (1916), the distance between the vent and the different outcrops was measured from the eastern vent.

\section{Unit T1}

At several sites located along the dispersal axis in proximal and medial areas, the base of the Taisho sequence is formed by a reversely graded lapilli bed (thickness $=12 \mathrm{~cm} ; \operatorname{Md} \phi=-2.1$, $\sigma \phi=1.93$ at section 10; Figs. 3, 4, and 5). The unit is homogeneous in terms of components, being dominated by lighttoned pumice lapilli, with rare $(<1 \%$ by weight) low-tomoderately vesicular dark pumice. At a distance of 20 $30 \mathrm{~km}$ from the vent (sections 3 to 6 ; Fig. 5), Unit T1 is a thin, 3-5-cm-thick layer, composed by a moderately sorted, fine lapilli-bearing lower part, overlain by a well-sorted top bed of coarser pumice lapilli clasts $(0.5-1 \mathrm{~cm}$ in diameter).

\section{Unit T2}

Unit T2 consists of a faintly-to-moderately stratified deposit formed by alternating centimeter- to decimeter-thick coarse and fine lapilli beds. At section 10, several beds can be distinguished and form a 50-cm-thick deposit $(\mathrm{Md} \phi$ from -1.77 to -1.05 , $\sigma \phi$ from 1.94 to 1.75 ). Across medial areas, the beds progressively grade away from the vent into a massive and poorly sorted deposit, in which a better-sorted layer of coarse lapilli can still be recognized only in the middle part of the unit.

\section{Unit T3}

Unit T3 is a moderately sorted, lapilli-bearing deposit $(\operatorname{Md} \phi=-1.3, \sigma \phi=1.85$ at section 10$)$ characterized by a distinctive increase in the content of low-to-moderately vesicular dark pumice and lithic fragments compared to Units T1 and $\mathrm{T} 2$. The deposit is normally graded at reference section 10 (15 $\mathrm{cm}$ thick), and it preserves this appearance at several sections along the dispersal axis (sections 7, 13, and 6; Figs. 3 and 5). Farther from the vent, the unit grades into a massive, fine lapilli-bearing bed.

\section{Unit T4}

Unit T4 is a fine-to-coarse ash bed capping the Taisho sequence in the sector south of the main dispersal axis identified for Units T1 to T3. The unit is well exposed at section 14 (Fig. 4b), where it reaches the maximum observed thickness of $15 \mathrm{~cm}$. The base of the unit is formed by a moderately sorted, $3-\mathrm{cm}$ thick layer of coarse ash, overlain by a well-sorted 1.5 -cm-thick fine ash layer. The upper part comprises a well-sorted 1-cmthick coarse ash layer underlying a well-sorted, 10-cm-thick, massive fine ash layer. Farther from the vent in the SE direction (e.g., at sections 4, 25, and 27; Fig. 3), Unit T4 is massive. At section 22, the whole of the Taisho sequence consists of a 5cm-thick, partially eroded bed of Unit T4.

\section{Tephra dispersal and lateral variations}

Taisho tephra Units $\mathrm{T} 1$ to $\mathrm{T} 3$ were dispersed to the ESE by prevailing winds (Fig. 6a). Along the dispersal axis, up to medial sites, the deposits progressively thin out from $184 \mathrm{~cm}$ at section 11 to $11 \mathrm{~cm}$ at section 3 (Figs. 5 and $6 \mathrm{a}, \mathrm{b}$ ), and grain size decreases accordingly, passing from an $\mathrm{Md} \phi$ of -2.1 to 0.67 . While Unit $\mathrm{T} 1$ can always be recognized as a discrete layer composed of a moderately sorted, pumice-bearing, fine lapilli bed overlain by a well-sorted layer of coarse pumice lapilli, the separation between Units T2 and T3 becomes progressively unclear with distance from vent. Farther from the vent $(20-25 \mathrm{~km})$, the two units grade into a single massive and poorly sorted deposit (e.g., at sections 24, 9, and 3; Figs. 3 and 5). At the most distal outcrops, along the dispersal axis (at distances of $>40 \mathrm{~km}$; e.g., sections 31 and 32; Fig. 3), the deposit consists of a poorly sorted, coarse-to-fine ash bed mixed with soil, in which no coherent units can be clearly recognized. As a whole, the deposit shows a rather regular 
Fig. 5 Stratigraphic correlations of Taisho tephra units among selected outcrops along the main dispersal axis $\left(\mathrm{A}-\mathrm{A}^{\prime}\right)$ and along a transect across the main dispersal axis $\left(\mathrm{B}-\mathrm{B}^{\prime}\right)$. Grain size scale at the bottom of each section is indicated as fine $(\mathrm{F})$ and coarse (C) ash and lapilli according to the width of each column segment
A

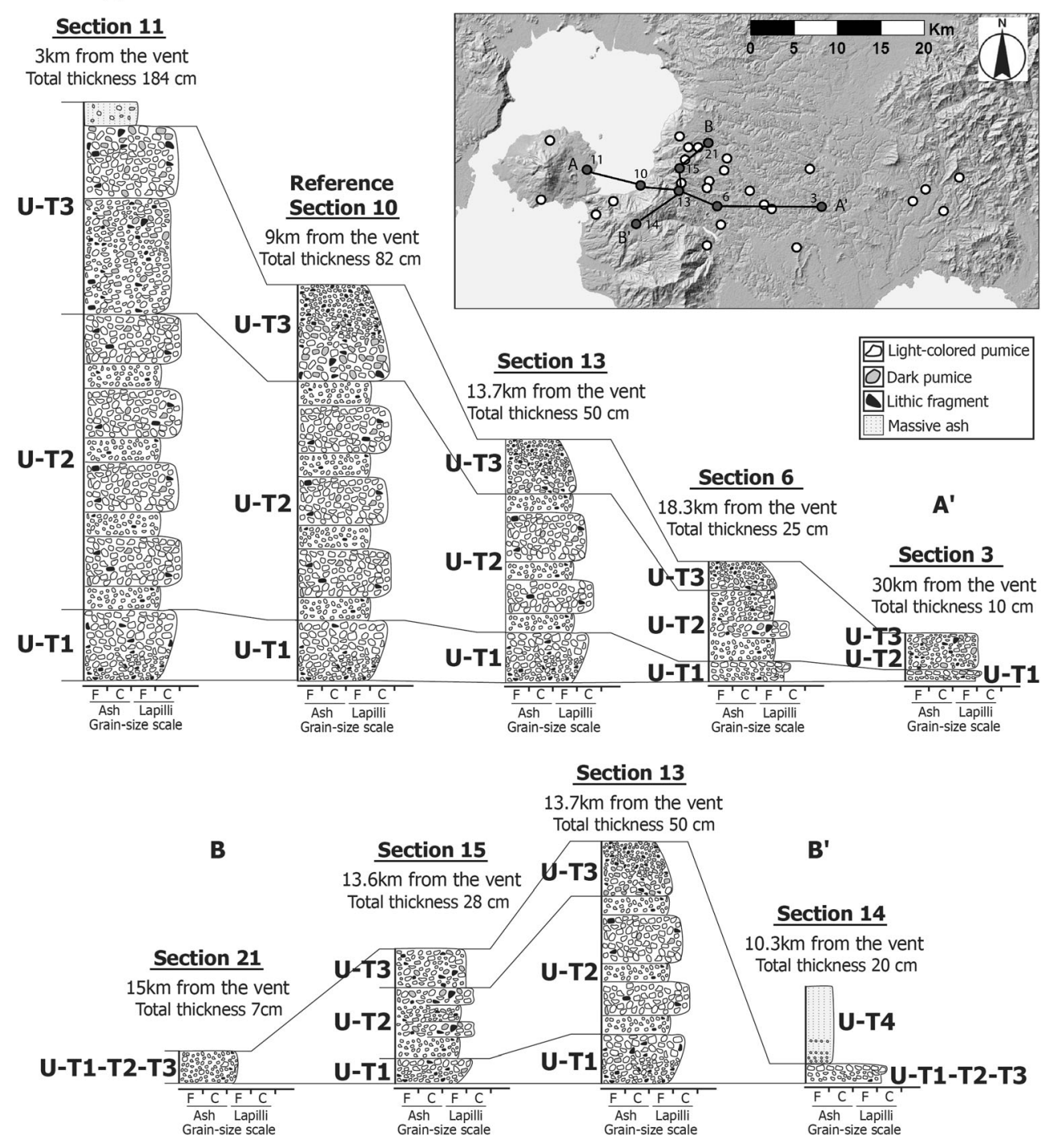

exponential decrease in thickness with distance (Fig. 6b). The isopach map of Taisho tephra Units T1 to T3 (Fig. 6a) has a slightly asymmetrical, narrow, and elongated form, with a less steep crosswind thickness decrease toward the northernmost sites (Fig. 6c). In transects across the dispersal axis, the three lapilli-bearing units thin out less rapidly to the NE and more rapidly toward the SE sector, where Unit T4 is dispersed and caps the sequence (Figs. 5 and 6a and SM1, Supplementary Material). North of the dispersal axis more than $5 \mathrm{~km}$ off the axis, the different units gradually merge into a single massive and moderately sorted deposit. Conversely, south of the axis, they merge into a 1.5 - to 5 -cm-thick, poorly sorted, fine to coarse lapilli-bearing bed, overlain by ashy Unit T4 (Fig. 5).

\section{Proximal fallout deposits}

Due to the multi-vent nature of the Taisho eruption, isopachs are wider in proximal areas (Fig. 6a), enclosing the two main vents on the opposite flanks of the volcano. This is also in agreement with the map of the proximal deposits given in Omori (1916). These fallout tephra deposits reach a maximum observed thickness $(184 \mathrm{~cm})$ at section 11 near the buried Kurokami temple (Fig. 3). Here, units T1 to T3 are clearly visible, and the deposit is capped by a 10 -cm-thick, poorly sorted, yellowish ash bed mixed with fine and coarse lapilli, tentatively assigned to Unit T4. Thick tephra deposits are also found outside of the main dispersal axis, on the northern and southern flanks of Sakurajima volcano, where they are around 80- and 40-cm-thick, respectively.

At section 26 (Fig. 3), on the northern flank of Kitadake, the deposit is a $77-\mathrm{cm}$-thick layer, formed by four distinct, well-sorted, coarse lapilli-bearing beds $(\mathrm{Md} \phi=-2.9$ to $-4.1)$. The grain size features of the deposit, and upwind location with respect to the eastern vents, suggest that this outcrop can be related to very proximal sedimentation from the western vents. 
Fig. 6 a Isopach map in centimeters of Taisho tephra units $\mathrm{T} 1$ to T3. Blue circles indicate sites in which deposits consist of lapilli-bearing beds (units T1 to T3), while yellow squares indicate sites in which the tephra sequence is capped by Unit T4; numbers in brackets next to the yellow circles refer to the thickness of Unit T4. Letter $t$ refers to those sites where Taisho is present as trace, and a discrete tephra layer cannot be identified. b, c Deposit thinning profiles of T1T3 sequence along the dispersal axis and two crosswind-sections shown in Fig. 5a. b Semi-log thickness vs. distance from eastern vent (dispersal axis: $\left.D-D^{\prime}\right)$. c Semi-log thickness vs. distance from the dispersal axis (crosswind-sections $\mathrm{C} 1, \mathrm{C} 2, \mathrm{C} 3, \mathrm{C} 4)$; the $0-\mathrm{km}$ point is set along the dispersal axis

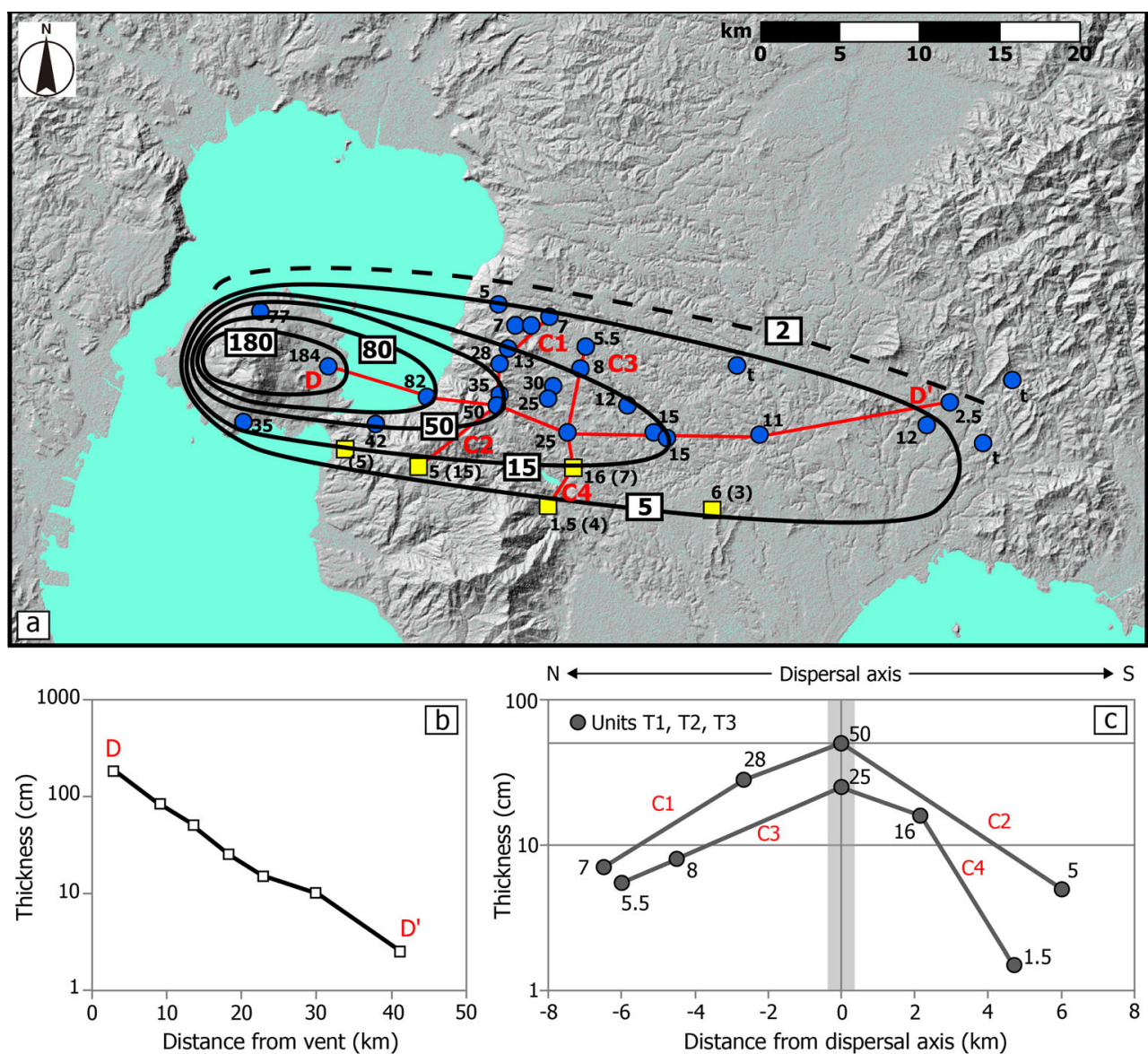

On the southern lower flank of Minamidake, a 30-cmthick, poorly sorted, faintly stratified, coarse-to-fine lapilli bed is exposed along a road cut (section 29; Fig. 3). This is overlain by a 5 -cm-thick massive, finer-grained bed. No deposit related to pyroclastic flows was found in the studied sections, distributed in the southern, northern, and eastern sectors of the volcano; according to the chronicles, in fact, pyroclastic flow deposits, if still visible, should be distributed mainly on a restricted area on the western sector of the volcano.

\section{Data from contemporary thickness measurements}

In their seminal work on the eruption, Omori (1916) and Koto (1916) also presented detailed isopach maps for tephra dispersal, based on measurements taken immediately after the eruption (Figs. SM2 and SM3, Supplementary Material). Although clearly indicating a preferential dispersal eastward, the two maps show a wider distribution of tephra around the volcano when compared to the preserved lapilli-bearing deposit visible today (Fig. 6a). Dispersal maps clearly reflect a multi-lobe distribution, with thicknesses up to $3 \mathrm{~cm}$ extending to distances of more than $30 \mathrm{~km}$ from the vent both to the NNE and to the NNW. Today, lack of preservation of deposits in such sectors suggests that these previously measured accumulations were probably related to ash emission that immediately followed the first 2 days of the eruption. These deposits were either amalgamated in the soil or were rapidly eroded and are thus no longer recognizable. In addition, the comparison between our dataset and the observations of Omori (1916) and Koto (1916) reveals an important difference between measured thicknesses at different sites (see Fig. 6 and Supplementary Material). Historical thickness data are, in fact, up to three times larger than the presently measurable thicknesses, especially in the case of deposits dispersed in the midrange (between 10 and $30 \mathrm{~km}$ ). It is important to note that both Omori (1916) and Koto (1916) accounted for T4 in their final measurements (while this is excluded in the map of Fig. 6). The two historical isopach maps were then integrated using the same three methods used for the new thickness data presented here. All these issues will be returned to in detail in the discussion section.

\section{Grain size}

Samples collected from Units T1, T2, and T3 at type section 10 (9 km from vent) show a general fining upward in the sequence, with slight oscillations related to the moderately stratified structure of Unit T2 (Fig. 7). The sorting coefficient 
$(\sigma \phi)$ remains nearly constant at $\sim 1.9 \phi$ in Units $\mathrm{T} 1$ and $\mathrm{T} 2$, but it decreases at the top of Unit T3. Grain size distributions are strongly skewed toward the coarser grain sizes, but all samples present multiple modes, with two modes in the coarser fraction (respectively between -3.5 and $-2 \phi$ and -1 and $0 \phi ;$ Fig. 7) and a third, poorly pronounced mode in the finest fraction (between 4 and 6申; Fig. 7).

Md $\phi$ values of total samples (T1 to T3) steadily decrease along the dispersal axis (Fig. 8). A general decrease with distance is also observed for the two off-axis sectors, with slightly higher values of $\mathrm{Md} \phi$ for samples in the sector to the northeast of the dispersal axis. Samples possibly related to activity from the western vents (section 26; Fig. 3 ) are the coarsest grained (Fig. 8). The highest $\mathrm{Md} \phi$ values are related to samples from Unit T4 (Fig. 8).

Due to the observed polymodality, the grain size distribution of each sample was deconvolved into two or three Gaussian subpopulations (Figs. 9a, b): SP1 (coarse lapilli subpopulation), with modal value between -4.5 and $-1 \phi$; SP2 (fine lapilli-to-coarse ash subpopulation), with a mode between -2 and $2 \phi$; and SP3 (fine ash subpopulation), with a mode between 4 and 6申 (Fig. 9c). Three subpopulations are present in $71 \%$ of the analyzed samples, while $29 \%$ of the samples are bimodal. The separation between SP1 and SP2 starts to be poorly defined after about $30 \mathrm{~km}$ from the vent, and the modes of the two subpopulations theoretically overlap at a distance of about $60 \mathrm{~km}$ (Fig. 10a). Beyond this distance, grain size distribution is only bimodal, consisting of SP2 and SP3 subpopulations. Samples from Unit T4 consist of only bimodal distributions. Samples with three modes are dominated by SP1 and SP2, typically showing a very large variability in their relative abundance (Fig. 9d). In contrast to the large variability in the abundance of SP1 and SP2, the weight fraction of SP3, both in bimodal and polymodal samples of units $\mathrm{T} 1, \mathrm{~T} 2$, and $\mathrm{T} 3$, remains nearly constant at a few percent (excluding the most distal samples, around $40 \mathrm{~km}$ from the vent, where SP3 $=41 \mathrm{wt} \%$ ).

In bimodal samples from Units T1, T2, and T3, SP2 is typically more abundant ( $>80 \%$ by weight) than SP3 (Fig. 9d). In contrast, the relative abundances of SP2 and SP3 in bimodal samples from Unit T4 vary more widely than those from the former three units, with SP3 varying between 24 and 69 wt\% (Fig. 9e). Samples also show a clear variation with distance from vent in the modal value of SP1 and SP2 (Fig. 10a), with a general increase away from vent, passing from about -4 to $-1 \phi$ for SP1 between the proximal and medial areas and from about $-2 \phi$ to $1.6 \phi$ for SP2 in proximal to distal area. Conversely, the SP3 mode remains nearly constant around $5 \phi$.
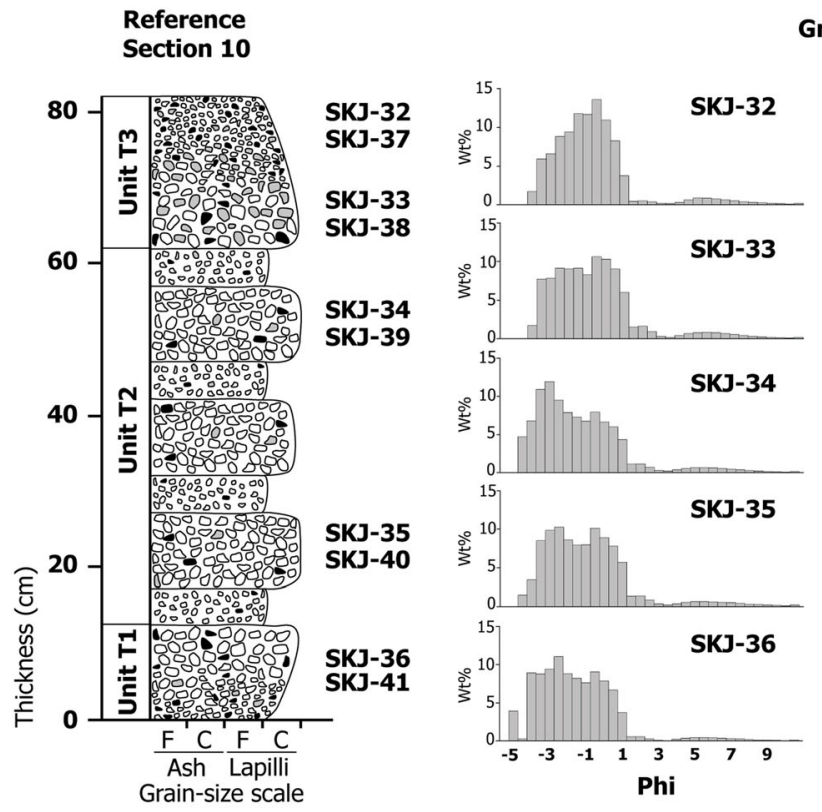

Fig. 7 Variation of the main sedimentological and physical properties of the deposit (grain size, componentry, and density) within the stratigraphic sequence at reference section 10. Samples collected for grain size analysis were then used for componentry analysis, performed in the lapilli and very coarse ash fraction $(-5.5 \phi$ to $-0.5 \phi)$; different samples (selected 100 -clast samples) were collected for density estimations. Numbers in
Grain-size

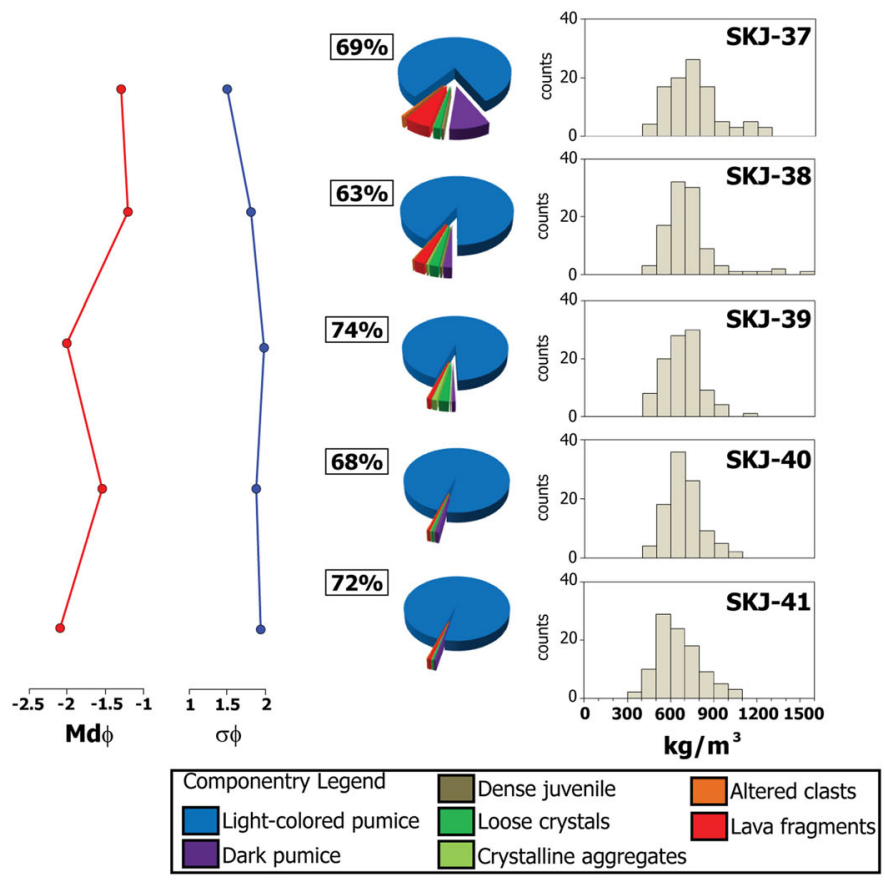

open rectangles indicate the wt $\%$ of respective samples investigated for componentry analysis. Letters $F$ ( $=$ fine) and $C$ (= coarse) associated with the grain size terms Ash and Lapilli at the bottom of the section refer to the mean grain size of tephra beds. Symbols $S K J-32$ refer to the sample ID number 


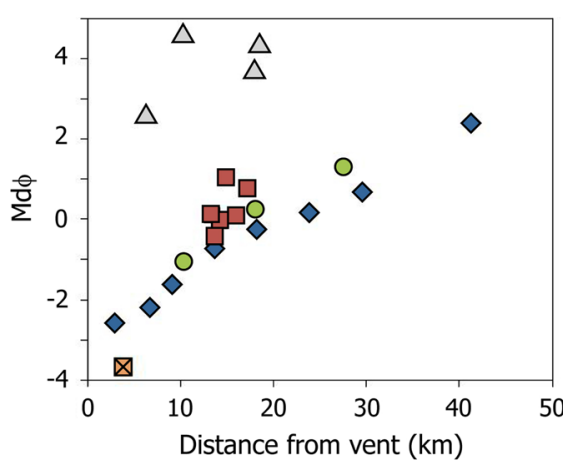

$\diamond$ Dispersal axis

$\square$ off-axis (ENE sector) O off-axis (SE sector)

凶Upwind

$\triangle$ Unit T4

Fig. 8 Variation with distance from eastern vent of $M d \phi$ values in Taisho lapilli-bearing deposits (averaged values for the units T1, T2, and T3, weighted following their thickness at each site). Symbols on the graph indicate the location of each sampled outcrop among the dispersal area. Md $\phi$ values of the ash Unit T4 are also reported in the graph using gray triangles

The abundance of each SP with distance does not vary regularly (Fig. 10b), possibly due to the observed difference in mean grain size of samples from the two off-axis sectors and to the vertical variation described for the deposits. SP2 shows a general increase in abundance in the medial sites (15-30 km from the vent), reaching up to $90 \mathrm{wt} \%$ of the total sample. SP3 weight fraction remains relatively constant in all the analyzed samples, being $<10 \%$ along the dispersal axis up to $\sim 30 \mathrm{~km}$ from the vent.
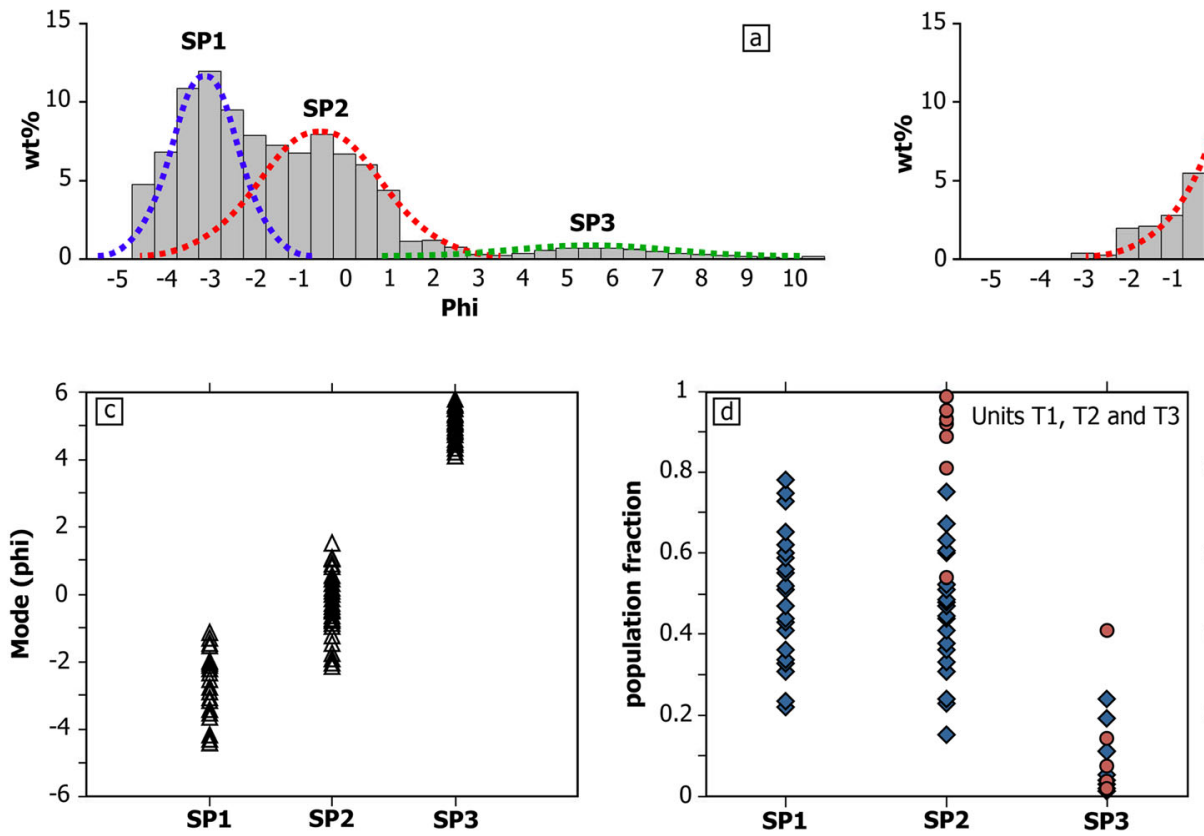

Fig. 9 Polymodality in the grain size distribution of samples from Taisho tephra deposit. Examples of polymodal grain size distribution, with three or two modes, in samples collected at $9 \mathrm{~km}$ (a) and $30 \mathrm{~km}(\mathbf{b})$ respectively from eastern vent; red dashed lines indicate the Gaussian subpopulations obtained with SFT software (Wohletz et al., 1989). Subpopulations are indicated as SP1 (coarse lapilli subpopulation), SP2 (fine lapilli to coarse
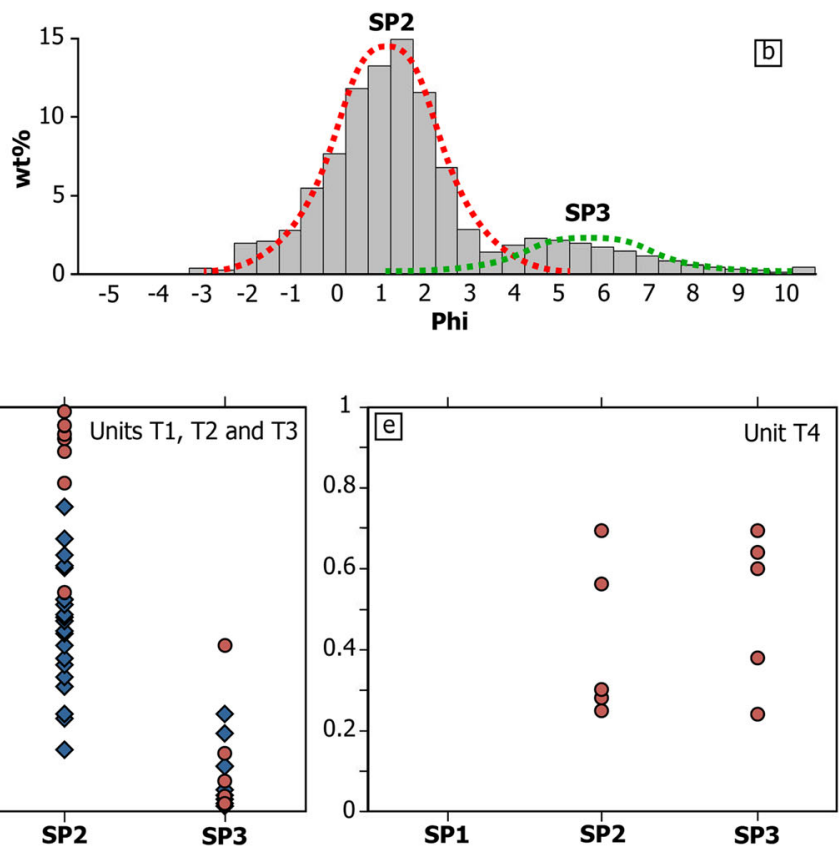

\section{Componentry and density}

Component analysis was performed on samples of Units T1, $\mathrm{T} 2$, and $\mathrm{T} 3$ from reference section 10. Based on macroscopic features of the clasts (color, external morphology, presence and extent of alteration, crystallinity, and vesicularity) observed in each size fraction coarser than $-0.5 \phi$, some main component classes were recognized.

Juvenile clasts show a large variability of macroscopic types and are grouped into five different categories: lighttoned pumice, dark pumice, dense clasts, loose crystals, and crystal aggregates. Banded pumice clasts are also present as a minor component. Lithic material consists almost entirely of both unaltered and altered lava fragments. Results obtained from component analysis are shown in Fig. 7 and listed in Table 1. Nakamura (2006) presents an extensive study of textural features of the volcanic products of the eruption, dividing pumice fragments into three types in terms of vesicularity and plagioclase microlite texture. Types 1 and 2 respectively represent white pumice with high vesicularity (> 55-60 vol\%) and low-to-intermediate microlite content (from $<1.0$ to $11 \mathrm{vol} \%)$. Type 3 is a slightly darker pumice with low vesicularity (25-50 vol\%) and intermediate-to-high microlite content ( $8-16$ vol\%). Types 1 and 2 are here tentatively related to the light-toned pumice category, while type 3 pumice, less vesicular than the others, possibly corresponds to the dark pumice category.

ash subpopulation), and SP3 (fine ash subpopulation). $\mathbf{c}$ Range of subsubpopulation weight fractions in samples from Units T1, T2, and T3; red circles and blue diamonds indicate bimodal and polymodal samples, respectively. c Range of subpopulation weight fractions in samples from Unit T4 population modes from Taisho samples (Units T1 to T4). d Range of 

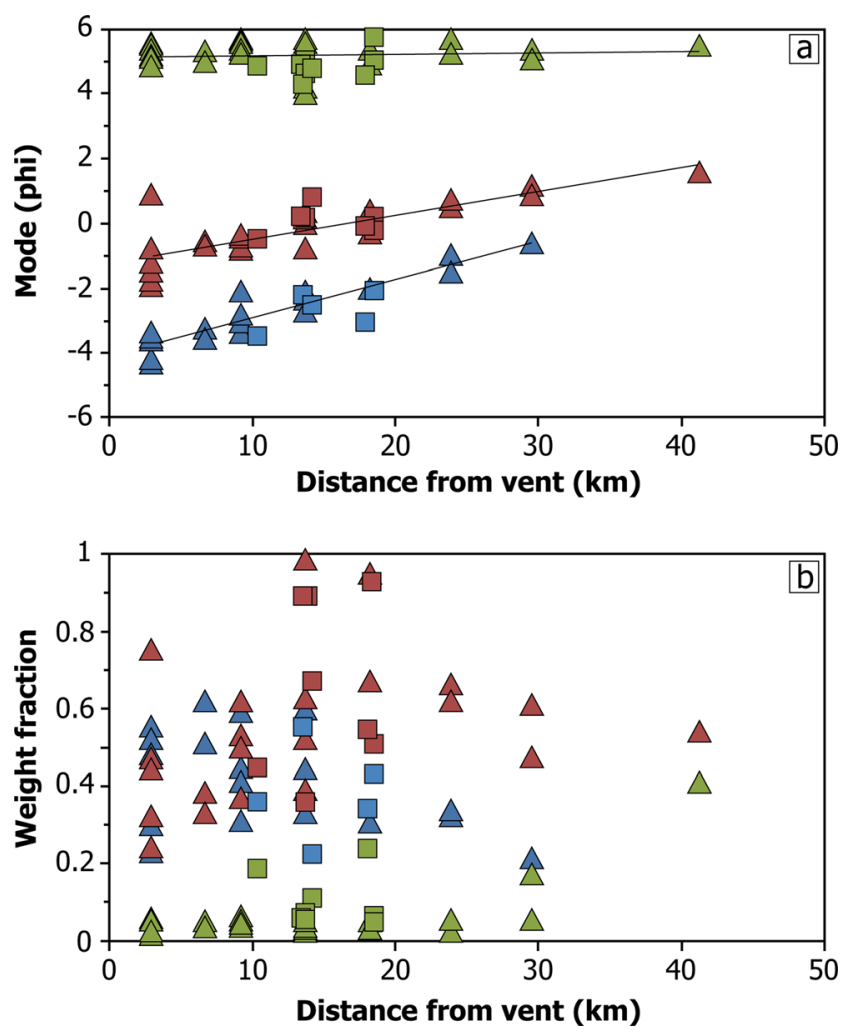

Fig. 10 Mode vs. distance from eastern vent (a) and weight fraction vs. distance from eastern vent plots (b) of Gaussian grain size subpopulations from Taisho tephra deposits (units T1, T2, and T3). SP1, SP2, and SP3 are shown in blue, red, and green, respectively. Samples collected along the main dispersal axis are shown by triangles, while samples collected offaxis are shown by squares. Regression lines in plot (a) are traced for samples along the main dispersal axis. Unit T4 is not shown

\section{Juvenile material}

Light-toned pumice clasts are light gray, highly vesicular, generally porphyritic, plagioclase, and pyroxene-bearing clasts. Vesicles are generally millimetric in size $(<3-$ $4 \mathrm{~mm}$ in diameter) and range in shape from spherical to irregular (possibly due to coalescence and/or collapse). Tubular vesicles are rare and generally associated with slightly elongated clasts. These clasts represent the most abundant component within the eruptive sequences and throughout all the different grain size classes. Abundance of this type of pumice clasts progressively decreases from the base (98 wt\%) to the top ( $80 \mathrm{wt} \%)$ of the sequence (Fig. 7).

Dark pumice clasts are poorly-to-moderately vesicular, dark gray, generally porphyritic clasts. Dark pumices are microvesicular, with minor or rare millimeter-sized (up to $2 \mathrm{~mm}$ in diameter), irregularly shaped, vesicles. Although present in all the units, this type of pumice is most abundant in the samples from Unit T3, reaching $10 \mathrm{wt} \%$ (Table 1).

Dense juvenile clasts are black-to-bright gray, poorly vesicular-to-dense, unaltered glassy fragments. Bright gray fragments are fluidal and have a vitreous luster and conchoidal fractures and possibly represent fragments of obsidian. The black, poorly vesicular fragments have plagioclase phenocrysts and spherical vesicles and possibly represent the denser end member of dark pumice clasts. Although dense juvenile fragments are sparsely present throughout units $\mathrm{T} 1$ to $\mathrm{T} 3$, their abundance is always relatively low (maximum $0.6 \mathrm{wt} \%$ ), increasing upward in the sequence (Table 1).

Free crystals are free crystals consisting of plagioclase with subordinate pyroxene and rare oxides. Crystal lengths vary from $<1$ up to $4 \mathrm{~mm}$. They only occur in fractions between -2 and $-0.5 \phi$, and their abundance (from 0.3 to $2.6 \mathrm{wt} \%$; Table 1) is higher in the upper part of T2 and in the lower part of T3, increasing toward the finer-grained fractions.

Crystal aggregates are composed of pyroxene, plagioclase, and subordinate olivine. Crystals from aggregates are scarce $(<0.5-1 \mathrm{wt} \%)$ and finer-grained in respect to those in the loose crystal category. Crystal aggregates are often found attached to the external surface of the pumice clasts. Their abundance is higher in samples richer in loose crystals (Table 1).

\section{Lithic material}

Lava fragments are black-to-dark gray, mostly aphyric-toporhyritic lava fragments. They do not show a wide variability, and their abundance is always lower than a few percent. Unit T3 has the highest proportion.

Altered clasts are variably altered lava fragments, which range from partially-to-completely oxidized. In some case, pervasive alteration makes recognition of the original

Table 1 Componentry data expressed in weight percent obtained from component analysis of samples collected at the reference section 10 of Fig. 3

\begin{tabular}{lllllllll}
\hline Sample ID & Tephra unit & Light-co. pumice & Dark pumice & Dense juvenile & Loose crystals & Crystal aggregates & Lava fragment & Altered clasts \\
\hline SKJ-32 & Unit T3 & 80.65 & 10.01 & 0.59 & 1.59 & 0.06 & 6.37 & 0.73 \\
SKJ-33 & Unit T3 & 91.68 & 2.12 & 0.48 & 2.25 & 0.52 & 2.73 & 0.21 \\
SKJ-34 & Unit T2 & 93.85 & 0.97 & 0.27 & 2.61 & 1.31 & 0.84 & 0.15 \\
SKJ-35 & Unit T2 & 97.30 & 1.02 & 0.18 & 0.53 & 0.21 & 0.55 & 0.22 \\
SKJ-36 & Unit T1 & 97.95 & 0.47 & 0.03 & 0.36 & 0.19 & 0.75 & 0.25 \\
\hline
\end{tabular}


lithology difficult. Their abundance never exceeds $0.7 \mathrm{wt} \%$ and has an increasing trend in Unit $\mathrm{T} 3$.

Observed vertical variation of componentry shows a general increase in denser juvenile material and in lithic clasts, as well as in loose crystals, at the top of Unit T2 and in Unit T3 (Fig. 7). These components are mainly concentrated in the finer-grained (between -0.5 and $-2 \phi$ ) part of the analyzed samples.

\section{Density of juvenile clasts}

The density of juvenile material was measured on 500 lighttoned pumice clasts between $-5 \phi$ and $-3 \phi$ from samples collected from the different units at section 10 . Density ranges from $\sim 400$ to $1500 \mathrm{~kg} / \mathrm{m}^{3}\left(703 \pm 150 \mathrm{~kg} / \mathrm{m}^{3}\right.$ on average), corresponding to vesicularities of 90 to $40 \%$, irrespective of clast size.

Density distribution is unimodal and slightly skewed toward high density values in samples from Units $\mathrm{T} 1$ and $\mathrm{T} 2$, with modes varying between 500 and $800 \mathrm{~kg} / \mathrm{m}^{3}$ (Fig. 7). The distribution is bimodal for Unit T3, with a primary mode at $700-800 \mathrm{~kg} / \mathrm{m}^{3}$ and a secondary mode at $1400-1500 \mathrm{~kg} / \mathrm{m}^{3}$ and $1100-1200 \mathrm{~kg} / \mathrm{m}^{3}$ for the bottom and top of the unit, respectively. A progressive variation in the first mode can be observed along the sequence passing from 500 to $600 \mathrm{~kg} / \mathrm{m}^{3}$ at the base of Unit T1 to $700-800 \mathrm{~kg} / \mathrm{m}^{3}$ at the top Unit T3. Histograms also show a narrower density range for Unit $\mathrm{T} 2$ (from 500 to $1100 \mathrm{~kg} / \mathrm{m}^{3}$ ) compared to those from Unit T1 and T3 (from 400 to $1500 \mathrm{~kg} / \mathrm{m}^{3}$ ).

\section{Largest clasts}

Data on the largest clasts at selected outcrops were used to compile isopleth maps. Due to the scarcity of lithic fragments, measurements of the largest clasts were performed on lighttoned pumice clasts. Clasts were selected from the whole deposit, irrespective of the unit, although in general unit T2 contains the largest clasts. The isopleth maps compiled with different strategies and combination of measures (see "Methods" section) resulted in similar geometry, with the isopleth contours displaying an elongate pattern (Fig. 11). The isopleth areas from G3/5-PD and G3/5-PAP are generally larger than those derived from clasts measurements using the 50th-PD and 50th-PAP methods (Fig. 12). Regardless of the method used, clast diameters estimated according to the PAP approach are always higher than those estimated using the PD approach. The average differences in clast dimensions are 8 and $9 \%$ considering the 50th and the G3/5 methods for the choice of the largest clast, respectively. On the other hand, whatever measuring approach is used (PD or PAP), adopting the G3/5 method to choose the representative largest clast results in clast diameters $30 \%$ higher on average than those obtained using the 50th method.

By comparing the dimension of the largest clasts obtained from different approaches and methods on the plot of log of the largest clast vs. square root of the isopleth area (Fig. 12), the slopes of the straight lines that best fit the observations (i.e., the rate at which clast size decreases from the source; Pyle 1989) have nearly the same value. Therefore, the maximum clast half-distance parameters, $b_{\mathrm{c}}$ (Pyle 1989), for the four sets of data are very similar, being $2.4 \mathrm{~km}$ on average.

\section{Tephra-deposit volume}

The volume of Units T1 to T3 of the Taisho tephra deposit resulting was estimated from the plot of log thickness vs. square root of the isopach area using the three different methods of integration described in the "Methods" section (Fig. SM4, Supplementary Material).

All thinning relationships fit well the field data. Resulting volumes of the total deposit vary between $0.25 \mathrm{~km}^{3}$ for the exponential method, $0.27 \mathrm{~km}^{3}$ (as an average for the three integration limits) for the power-law method, and $0.45 \mathrm{~km}^{3}$ for the Weibull method (Table 2). The average volume is $0.33 \pm 0.11 \mathrm{~km}^{3}$. The volume was converted to DRE-based mean deposit density of $676 \pm 189 \mathrm{~kg} \mathrm{~m}^{-3}$ as derived from direct measurements of the deposit (the mean deposit density varies between 535,765 , and $980 \mathrm{~kg} \mathrm{~m}^{-3}$ in proximal, medial, and distal outcrops, respectively), resulting in an average DRE volume of $0.09 \pm 0.03 \mathrm{~km}^{3}$. The corresponding mass of the erupted material is $2.2 \pm 0.7 \times 10^{11} \mathrm{~kg}$.

\section{Column height and eruption rates}

The different isopleth maps of largest pumice clasts (Fig. 11) were used for estimating the values of downwind and crosswind ranges, in order to apply the method of Carey and Sparks (1986) and to assess the maximum column height (peak phase of the eruption).

Plume heights (Table 3) vary between $13.2 \mathrm{~km}$ (50th-PAP method) and $16.4 \mathrm{~km}$ (G3/5-PAP method) above sampling height (average value of $15.0 \pm 1.2 \mathrm{~km}$ ). Given that the sampling locations are located at an altitude between 150 and $550 \mathrm{~m}$ a.s.l., and that the altitude of the craters on both the western and eastern fissures varies between 300 and $450 \mathrm{~m}$ a.s.l. (Omori 1916), plume height is above vent. Derived tropopause wind speeds do not vary greatly between the different methods and are always high, between 38 and $41 \mathrm{~m} \mathrm{~s}^{-1}$ (Table 3).

The peak of the volumetric discharge rate (VDR) for the total deposit was estimated following the relationships of Mastin et al. (2009): $H=2.00 \times(\mathrm{VDR})^{0.241}$ (with $H$ being 

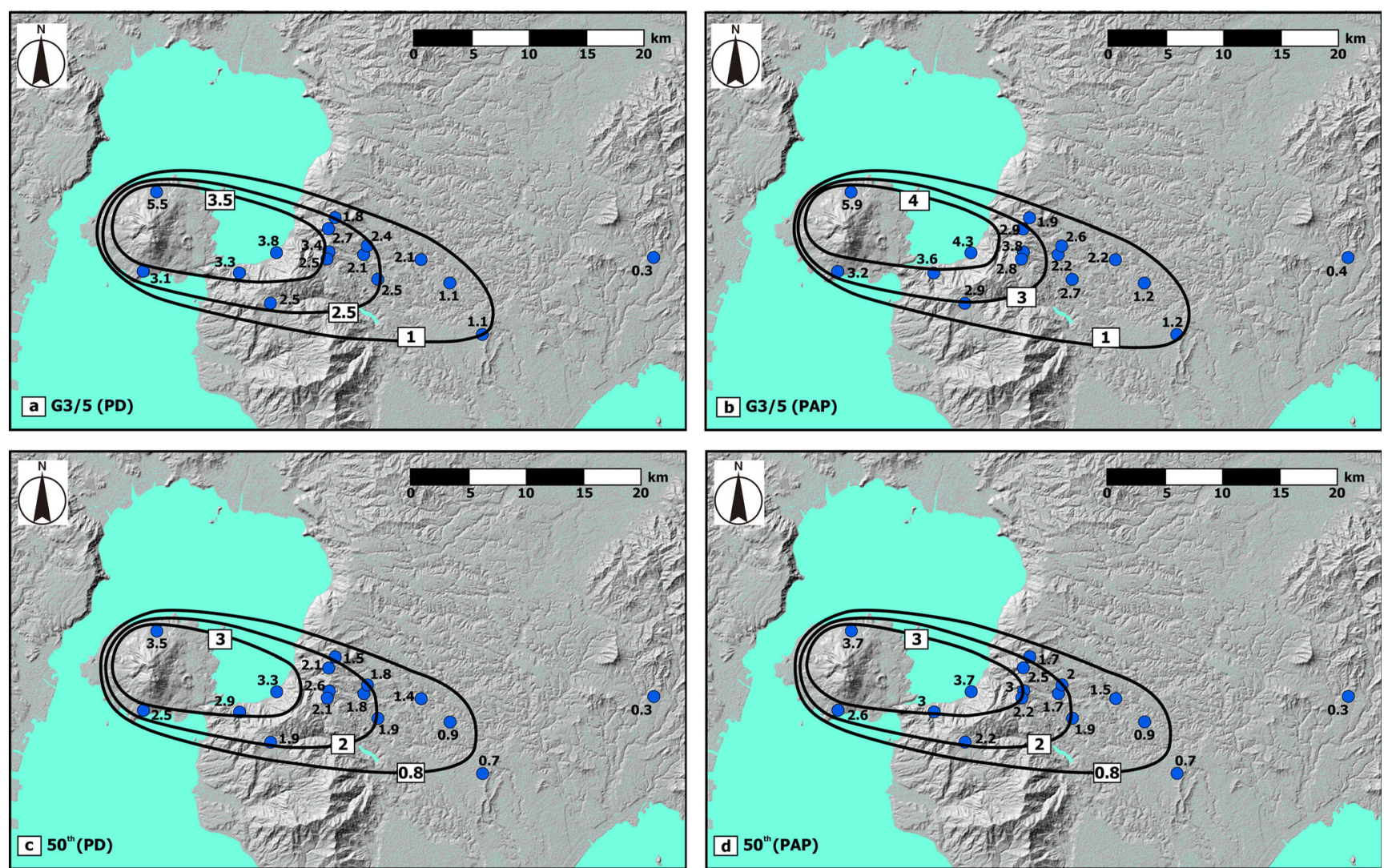

Fig. 11 Taisho isopleth maps, in centimeters, of the largest pumice clasts compiled with the G3/5 (a PD; b PAP) and 50th (c PD; d PAP) strategies

the height in $\mathrm{km}$ of the eruptive plume above the vent and VDR in $\mathrm{m}^{3} \mathrm{~s}^{-1}$ ). Estimated VDR results yield $4.3 \pm 1.4 \times$ $10^{3} \mathrm{~m}^{3} \mathrm{~s}^{-1}$. MDR was then calculated from VDR, resulting in a value of $1.1 \pm 0.4 \times 10^{7} \mathrm{~kg} \mathrm{~s}^{-1}$.

Given the strong wind advection of the volcanic cloud, MDR was also calculated based on the method of Degruyter

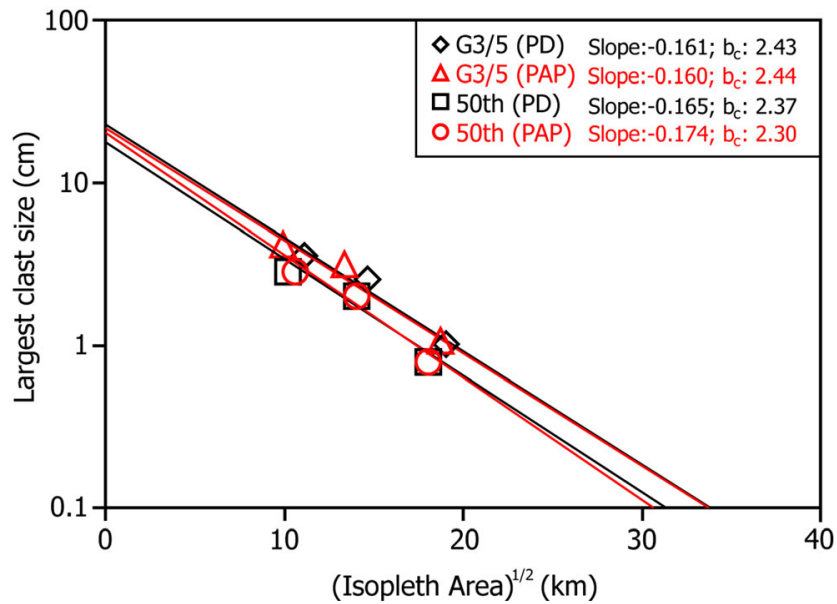

Fig. 12 Comparison of the size of the largest clast of the Taisho tephra deposit estimated with the four different methods in the semi-log plot of clast size $(\mathrm{cm})$ vs. the square root of isopleth area $(\mathrm{km})$ (from Fig. 11). The slope of the best fit line and the $b_{\mathrm{c}}$ parameter (Pyle, 1989) obtained from the four sets of data are reported in the plot and Bonadonna (2012) that accounts both for atmospheric (e.g., wind advection and atmospheric stratification) and eruptive parameters (e.g., plume height and magma temperature). Considering a magma temperature of $1323 \mathrm{~K}$ (for andesitic magmas), a tropopause height of $15 \mathrm{~km}$, and a plume height estimated with the method of Carey and Sparks (1986) for the different isopleths (Table 3), a MDR of $3.6 \pm 1.2 \times 10^{7} \mathrm{~kg} \mathrm{~s}^{-1}$ was calculated, which is three times the value obtained with the empirical equation suggested by Mastin et al. (2009). However, it is important to bear in mind that uncertainties

Table 2 Volumes of the tephra deposits associated with the subPlinian phase of the Taisho eruption estimated by integrating the fits of three different empirical thinning relationships (exponential, power-law, and Weibull)

\begin{tabular}{llll}
\hline & Deposit volume $\left(\mathrm{km}^{3}\right)$ & DRE volume $\left(\mathrm{km}^{3}\right)$ & Mass $(\mathrm{kg})$ \\
\hline Exponential & 0.25 & 0.068 & $1.71 \times 10^{11}$ \\
Power-law & 0.27 & 0.073 & $1.84 \times 10^{11}$ \\
Weibull & 0.45 & 0.122 & $3.05 \times 10^{11}$ \\
\hline
\end{tabular}

Volumes derived with the power-law method are average values of the three sets of integration limits applied (see text for detail). Volume results are converted into mass by applying an average deposit density of $676 \mathrm{~kg} \mathrm{~m}^{-3}$. DRE volume is calculated based on a magma density of $2500 \mathrm{~kg} \mathrm{~m}^{-3}$ 
Table 3 Maximum column height (Ht) of Taisho eruption and associated wind speed derived from the method of Carey and Sparks (1986) using the implementation of Biass et al. (2015), applied to four different isopleth maps compiled with different methods of maximum clast size characterization (G3/5 (PD), 50th (PD), G3/5 (PAP), and 50th (PAP))

\begin{tabular}{|c|c|c|c|c|c|c|c|c|c|c|}
\hline \multirow{2}{*}{$\begin{array}{l}\text { Max clast } \\
\text { method }\end{array}$} & \multirow{2}{*}{$\begin{array}{l}\text { LC size } \\
(\mathrm{cm})\end{array}$} & \multirow{2}{*}{$\begin{array}{l}\text { Clast } \\
\text { density } \\
\left(\mathrm{kg} / \mathrm{m}^{3}\right)\end{array}$} & \multirow{2}{*}{$\begin{array}{l}\text { DW range } \\
(\mathrm{km})\end{array}$} & \multirow{2}{*}{$\begin{array}{l}\text { CW range } \\
(\mathrm{km})\end{array}$} & \multirow{2}{*}{$\begin{array}{l}\mathrm{Ht} \\
(\mathrm{km})\end{array}$} & \multirow{2}{*}{$\begin{array}{l}\text { Wind } \\
\text { speed } \\
(\mathrm{m} / \mathrm{s})\end{array}$} & \multicolumn{2}{|c|}{ Mastin et al. (2009) } & \multicolumn{2}{|c|}{ Degruyter and Bonadonna (2012) } \\
\hline & & & & & & & $\operatorname{VDR}\left(\mathrm{m}^{3} / \mathrm{s}\right)$ & $\operatorname{MDR}(\mathrm{kg} / \mathrm{s})$ & $\operatorname{VDR}\left(\mathrm{m}^{3} / \mathrm{s}\right)$ & $\operatorname{MDR}(\mathrm{kg} / \mathrm{s})$ \\
\hline \multirow[t]{3}{*}{$\mathrm{G} 3 / 5$ (PD) } & 1 & 500 & 35.28 & 5.71 & 16.2 & 41 & $5.88 \times 10^{3}$ & $1.47 \times 10^{7}$ & $1.96 \times 10^{4}$ & $4.90 \times 10^{7}$ \\
\hline & 2.5 & 620 & 24 & 4.84 & 16.0 & 39 & $5.59 \times 10^{3}$ & $1.40 \times 10^{7}$ & $1.83 \times 10^{4}$ & $4.58 \times 10^{7}$ \\
\hline & 3.5 & 670 & 18.45 & 3.53 & 14.3 & 39 & $3.51 \times 10^{3}$ & $8.77 \times 10^{6}$ & $1.04 \times 10^{4}$ & $2.61 \times 10^{7}$ \\
\hline \multirow[t]{3}{*}{ 50th (PD) } & 0.8 & 500 & 33.37 & 5.84 & 16.2 & 39 & $5.88 \times 10^{3}$ & $1.47 \times 10^{7}$ & $1.96 \times 10^{4}$ & $4.90 \times 10^{7}$ \\
\hline & 2 & 620 & 23.84 & 4.68 & 15.3 & 38 & $4.64 \times 10^{3}$ & $1.16 \times 10^{7}$ & $1.43 \times 10^{4}$ & $3.57 \times 10^{7}$ \\
\hline & 3 & 670 & 16.52 & 3.31 & 13.4 & 36 & $2.68 \times 10^{3}$ & $6.69 \times 10^{6}$ & $8.08 \times 10^{3}$ & $2.02 \times 10^{7}$ \\
\hline \multirow[t]{3}{*}{ G3/5 (PAP) } & 1 & 500 & 35.28 & 5.81 & 16.4 & 41 & $6.19 \times 10^{3}$ & $1.55 \times 10^{7}$ & $2.09 \times 10^{4}$ & $5.22 \times 10^{7}$ \\
\hline & 3 & 620 & 21.85 & 4.35 & 15.4 & 39 & $4.77 \times 10^{3}$ & $1.19 \times 10^{7}$ & $1.48 \times 10^{4}$ & $3.70 \times 10^{7}$ \\
\hline & 4 & 670 & 16.62 & 3.15 & 13.7 & 39 & $2.93 \times 10^{3}$ & $7.34 \times 10^{6}$ & $8.80 \times 10^{3}$ & $2.20 \times 10^{7}$ \\
\hline \multirow[t]{3}{*}{ 50th (PAP) } & 0.8 & 500 & 33.37 & 5.84 & 16.2 & 39 & $5.88 \times 10^{3}$ & $1.47 \times 10^{7}$ & $1.96 \times 10^{4}$ & $4.90 \times 10^{7}$ \\
\hline & 2 & 620 & 23.84 & 4.68 & 15.3 & 38 & $4.64 \times 10^{3}$ & $1.16 \times 10^{7}$ & $1.43 \times 10^{4}$ & $3.57 \times 10^{7}$ \\
\hline & 3 & 670 & 18.65 & 3.23 & 13.2 & 39 & $2.52 \times 10^{3}$ & $6.29 \times 10^{6}$ & $7.60 \times 10^{3}$ & $1.90 \times 10^{7}$ \\
\hline
\end{tabular}

MP, DW, and CW refer to size of largest clast (LC) and values of downwind range and crosswind range, respectively, used to infer Ht. VDR refers to the peak of volumetric discharge rate, derived from the relationship of Mastin et al. (2009) and Degruyter and Bonadonna (2012). MDR refers to the peak of mass discharge rate calculated from VDR using a magma density of $2500 \mathrm{~kg} \mathrm{~m}^{-3}$

on eruptive and atmospheric parameters (e.g., plume height, magma temperature, and wind speed) and on model parameters (e.g., wind and plume entrainment coefficients) can result in large uncertainties in the calculation of MDR (see Degruyter and Bonadonna, 2012 and Bonadonna et al., $2015 \mathrm{c}$ for more details on these uncertainties). The wind effect on plume height can be quantified based on the ratio of the radial-entrainment and the wind-entrainment terms of the equation suggested by Degruyter and Bonadonna (2012) (parameter $\Pi$ ) which, for the Taisho plume, results in a value of 0.18 . Such a value, typical of transitional plumes such as those associated with the climactic phase of the Cordon Caulle 2011 eruption, indicates that wind played a significant, but not a dominating, role in determining the plume height (Bonadonna et al., 2015c).

\section{Classification of the eruption}

The characterization and classification of explosive eruptions is based on a large number of parameters mostly derived from the study of tephra deposits (Bonadonna et al. 2016). Different classification schemes (Walker 1973a; Pyle 1989; Bonadonna and Costa 2013) are applied here for the T1-T3 units of the Taisho eruption (Fig. SM5). Calculated dispersal and fragmentation indexes $\left(539 \mathrm{~km}^{2}\right.$ and $35 \%$, respectively; Table 4 and Fig. SM5, Supplementary Material) place the Taisho eruption into the Plinian field of the diagram of Walker (1973a), very close to the boundary between subPlinian and Plinian eruptions. Conversely, in the Pyle (1989) diagram, the eruption plots within the subPlinian field $\left(b_{\mathrm{t}}\right.$ and $b_{\mathrm{c}} / b_{\mathrm{t}}$ respectively of 1.9 and 1.26; Table 4 and Fig. SM5). The deposit was also classified using the scheme proposed by Bonadonna and Costa (2013), based on the fitting parameters of the Weibull distribution of the log (thickness) vs. square root of the isopach area $\left(\lambda_{\text {th }}\right)$, and of the $\log$ (max clast diameter) vs. square root of the isopleth area $\left(\lambda_{\mathrm{MP}}\right)$. The Weibull parameters $\lambda_{\text {th }}$ and $\lambda_{\mathrm{MP}} / \lambda_{\text {th }}$ have values of $6.08 \mathrm{~km}$ and 2.24 , respectively (Table 4 and Fig. SM5, Supplementary Material), plotting at the boundary between Plinian and subPlinian eruptions.

As already discussed, due to the scarcity of lithic clasts in the deposit, isopleth maps were drawn up for pumice clasts. We suggest that, in general, the use of pumice instead of lithic clasts should give higher values of the indexes $b_{\mathrm{c}}$ and $\lambda_{\mathrm{MP}}$, indicating a stronger decay of clast diameter with distance than if lithics are used, as the decrease in size with distance is less steep than for lithic clasts due to the preferential breakage of the largest pumices at proximal sites. This should also result in larger values of the $b_{\mathrm{c}} / b_{\mathrm{t}}$ or $\lambda_{\mathrm{MP}} / \lambda_{\mathrm{th}}$ ratios and in a potential underestimation of the intensity of the eruption with the classification scheme of Pyle (1989) or in an overestimation using the Bonadonna and Costa (2013) classification. For classification schemes, this can be a problem especially in cases (as for the Taisho eruption) in which data plot close to the separation lines between two different eruption styles (e.g., Plinian or subPlinian). However, the estimated values for MDR and plume height also indicate a subPlinian style based on the MDR vs. plume height classification scheme of Bonadonna and Costa (2013), a scheme that does not depend on the size decay of pumice clasts (Fig. SM5). Similar 
Table 4 Summary of the main eruptive source parameters obtained for the subPlinian phase of the Taisho eruption and list of the three couples of parameters used to apply the different classification schemes (Walker, 1973; Pyle 1989; Bonadonna and Costa, 2013)

\begin{tabular}{|c|c|}
\hline Deposit volume $\left(\mathrm{km}^{3}\right)$ & $0.33 \pm 0.11$ \\
\hline DRE volume $\left(\mathrm{km}^{3}\right)$ & $0.09 \pm 0.03$ \\
\hline Mass erupted (kg) & $2.2 \pm 0.7 \times 10^{11}$ \\
\hline Maximum column height $(\mathrm{km})$ & $15.0 \pm 1.2$ \\
\hline MDR (kg/s) (Degruyter and Bonadonna 2012) & $3.6 \pm 1.2 \times 10^{7}$ \\
\hline VDR $\left(\mathrm{m}^{3} / \mathrm{s}\right)$ (Degruyter and Bonadonna 2012) & $1.4 \pm 0.5 \times 10^{4}$ \\
\hline MDR (kg/s) (Mastin 2009 & $1.1 \pm 0.4 \times 10^{7}$ \\
\hline $\operatorname{VDR}\left(\mathrm{m}^{3} / \mathrm{s}\right)($ Mastin 2009) & $4.3 \pm 1.4 \times 10^{3}$ \\
\hline Magnitude (Pyle 2015) & 4.34 \\
\hline Eruptive intensity (Pyle 2015) & 10.04 \\
\hline Dispersal index $\left(\mathrm{km}^{2}\right)$ (Walker 1973) & 539 \\
\hline Fragmentation index (\%) (Walker 1973) & 35 \\
\hline$b_{\mathrm{t}}(\mathrm{km})$ (Pyle 1989) & 1.9 \\
\hline$b_{\mathrm{c}}(\mathrm{km})($ Pyle 1989) & 2.4 \\
\hline$\lambda_{\text {th }}($ Bonadonna and Costa 2013) & 6.08 \\
\hline$\lambda_{\mathrm{MP}}($ Bonadonna and Costa 2013) & 13.6 \\
\hline $\begin{array}{l}\text { Sedimentation rate (Unit } \mathrm{T} 1 \text { and main body } \\
\text { of Unit } \mathrm{T} 2 ; \mathrm{cm} / \mathrm{h} \text { ) }\end{array}$ & 8 \\
\hline $\begin{array}{l}\text { Sedimentation rate (upper part of Unit } \mathrm{T} 2 \text { and } \\
\text { Unit } \mathrm{T} 3 ; \mathrm{cm} / \mathrm{h} \text { ) }\end{array}$ & 4 \\
\hline
\end{tabular}

Sedimentation rate of the fall Units T1, T2, and T3 at proximal sites along the dispersal axis are also listed

eruptive parameters are also indicated by Cioni et al. (2008) as typical of subplinian I eruptions at Vesuvius. It is important to note that both the classification of Bonadonna and Costa (2013) and that of Cioni et al. (2008) are related to the climactic phase of the eruption (Unit T2 in the case of Taishe eruption). On the contrary, the classification schemes of Walker (1973a), Pyle (1989), and Bonadonna and Costa (2013) are related to the cumulative deposit associated with units $\mathrm{T} 1$ to T3. Given the results of the application of different classification strategies, which all indicate subplinian-to-Plinian eruption styles, we suggest that classifying the eruption as subplinian is justified, while being well aware that it possibly represents a high-intensity end member of subPlinian activity.

\section{Discussion}

\section{The evolution of the eruption}

The reconstruction of the eruption that can be derived from our stratigraphic analysis is consistent with the available descriptions and the numerous eyewitness accounts (Omori 1916; Koto 1916). The activity of the first 2 days of the eruption (i.e., the subPlinian explosive phase) is well recorded in the deposits recognized up to a distance of at least $40 \mathrm{~km}$ from the vent (Units T1 to T3). As clearly described in the chronicles, the first 2 days of the eruption were dominated by explosive activity with the generation of two eruptive plumes from the main vents. Field data suggest that the main activity was from the eastern vents, in agreement with the accounts of Omori (1916). Proximal deposits do not record any deposit from the pyroclastic flow activity, clearly described in the chronicles for the western vents during the climax of the subPlinian phase.

The internal stratigraphy of the deposits, characterized by a high frequency oscillation (especially in Unit T2) of grain size, records the occurrence of changes in eruption intensity. Magma discharge peaked during deposition of Unit T2, as suggested by the general occurrence, throughout the whole dispersal area, of largest clasts in the upper half of this unit.

A progressive waning in eruption intensity occurred in correspondence of Unit T3, well evidenced by the fining upward of this unit in medial and distal deposits. The different dispersal and the fine grain size shown by Unit T4 is consistent with important changes that occurred in the eruption dynamics during this phase. We relate this to the activity following the subPlinian explosive phase, characterized by the development of low-altitude eruptive plumes that dispersed material over a limited area with respect to the preceding phase. In the proposed reconstruction of the activity, Unit T1 and the lower part of Unit T2 represent the first $13 \mathrm{~h}$ of the subPlinian eruption (between 10 am and 11 pm on January 12), with the main part of Unit T2 recording the climax of this phase (between $11 \mathrm{pm}$ on January 12 and 5 am on January 13). The upper portion of Unit T2 and the whole of Unit T3 can be related to the progressive waning of the subPlinian phase, until the afternoon of January 13 when the subPlinian phase ended. Combining data from DRE volume of the deposits and the estimated peak MDR (and related uncertainties), we obtain a minimum duration for the subplinian phase of the eruption of 3 and $11.5 \mathrm{~h}$ using the MDR resulting from Mastin et al. (2009) and between 1.5 and $2.5 \mathrm{~h}$ using the MDR estimated with the Degruyter and Bonadonna (2012) approach. This minimum duration is several times shorter than the observed duration of the activity (around $35 \mathrm{~h}$ ), suggesting that the phase of peak discharge persisted only for a very short time, and MDR of the entire eruption was possibly about one order of magnitude lower. This factor could be useful for reporting estimates of minimum duration calculated from the deposits of Plinian and subPlinian eruptions and relating them to the actual duration of the eruption itself. According to this interpretation, the sedimentation rate along the dispersal axis at proximal sites (about $4 \mathrm{~km}$ from the eastern vent) varied from about $8 \mathrm{~cm} / \mathrm{h}$ during deposition of Unit $\mathrm{T} 1$ and the main body of Unit $\mathrm{T} 2$ to $4 \mathrm{~cm} / \mathrm{h}$ during deposition of the upper part of Unit T2 and Unit T3. These values rapidly decreased downwind, halving by a distance of about $10 \mathrm{~km}$ from the vent. Finally, the ash-bearing deposits of Unit T4 can be interpreted as the result of ash accumulation during the lower intensity activity which 
developed in the first days after the subPlinian phase, lasting possibly until January 19 , when the dispersal was estimated to be restricted in a $200-\mathrm{km}$ radius around the vent. Onset of the effusive activity, although not completely clear from the chronicles, can be placed during the evening of the second day of the eruption (January 13).

\section{Comparison of thickness and erupted volumes with data from contemporary sources}

Dispersal maps built at the time of the eruption (Figs. SM2 and SM3, Supplementary Material) report deposits up to three times thicker with respect to those measured in this work, as well as to those presented by other authors (Kobayashi et al. 2013). Although the dataset collected in this paper only refers to the T1-T3 sequence, the observed difference between the two datasets is always larger than the general thickness of Unit T4. In fact, Unit T4, mainly dispersed to southeast, rapidly thins out from the vent from a maximum of $18 \mathrm{~cm}$ in proximal areas (Omori 1916) to only few centimeters in medial deposits, where the difference between the two datasets is still more than $30 \mathrm{~cm}$. For this reason, the difference between the thickness values reported in historical documents and those measured in this study has to be related to other "external" causes as:

- Thickness overestimation of the measurements in the aftermath of the eruption

- Erosional effects at top of the fallout deposit

- Post-depositional compaction

The problem of a general overestimation of tephra thickness in the chronicles should be considered, as data for other historical eruptions from Japan seem to show the same problem. Overestimation of thickness could be related to the possibility that data collected by local authorities are representative of local maximum accumulation, derived from measuring the deposits in proximity to obstacles that could have disturbed the free accumulation of tephra (e.g., roofs, buildings, vegetated areas).

Extended erosion on top of the tephra sequence could also offer an alternative explanation for the difference observed between the two datasets. However, the ubiquitous presence of deposits from Unit $\mathrm{T} 3$ in all the proximal sites suggests that erosion, if present, at maximum involved Unit T4 and possibly only the upper part of Unit T3, so being not sufficient to explain the large difference observed in thickness values (Figs. SM2 and SM3, Supplementary Material). In addition, where Unit T4 is still present on top of the sequence, thickness data from Koto (1916) and Omori (1916) are still significantly larger than those measured nowadays, further reducing the importance of erosional processes in explaining these discrepancies.
Post-depositional compaction of deposits is another process often invoked to explain differences between thickness of deposits measured at different times (e.g., Larsen and Eiríksson, 2008). This effect is, however, controversial. Some authors suggest that compaction has a very important effect on tephra deposits, reducing their volume by about $40 \%$ (Thorarinsson 1954; Larsen et al. 2008; Engwell 2013), and other authors clearly state that compaction is effective mainly on distal, ashbearing deposits, but it may have no effect at all on mid-distal to proximal, coarse-grained tephra (Hildreth and Drake 1992). This can be explained in terms of the average grain size of the compacting bed, with compaction being more effective in finegrained, ash-bearing deposits. Density measures of fine lapillito-ash deposits, sampled until February 1914 and presented by Omori (1916), vary between 810 and $1020 \mathrm{~kg} \mathrm{~m}^{-3}$ (average value of $910 \mathrm{~kg} \mathrm{~m}^{-3}$ ). These values are very similar to our measurements of deposit density for distal fine-grained deposits, which were found to vary between 900 and $1060 \mathrm{~kg} \mathrm{~m}^{-3}$ (average value of $980 \mathrm{~kg} \mathrm{~m}^{-3}$ ), so suggesting that postemplacement compaction of Taisho deposits could have been responsible for no more than a $10 \%$ reduction in thickness.

An important contribution to this problem comes from the study of http://researchrepository.murdoch.edu.au/5785, who demonstrated the very important effect of the presence of grass on the depositional surface in disturbing the overall thickness of the bed; measures repeated in a period of few months showed a progressive thickness reduction of more than $50 \%$ for deposits emplaced on grassland (http:// researchrepository.murdoch.edu.au/5785). As many of the thickness data reported in the chronicles were collected in tobacco plantations (Omori 1916), we suggest that the effect of the presence of vegetation on the depositional surface and the subsequent compaction could explain the large difference between observed and measured thicknesses.

Whatever the cause of the observed thickness discrepancy, our estimation of tephra volume considers only the well-preserved, lapilli-bearing deposit related to the subPlinian explosive activity. For this reason, we present here also the estimates for the volume (and mass) of the whole tephra deposit obtained using the isopach maps of Omori (196) and Koto (1916). These can be considered as a maximum for the studied deposit. Volumes from the integration of these isopach maps vary from $0.51 \pm 0.24 \mathrm{~km}^{3}$ (Omori, 1916) and $0.77 \pm 0.03 \mathrm{~km}^{3}$ (Koto, 1916). Accordingly, DRE volumes vary between 0.09 and $0.22 \mathrm{~km}^{3}$, respectively, 1.5 and 2.5 times larger than the DRE volume derived from our isopach map. Average MDR calculated for a total duration of $35 \mathrm{~h}$, is $4.06 \times 10^{6} \mathrm{~kg} \mathrm{~s}^{-1}$, still in the accepted range for Subplinian eruptions (Cioni et al. 2015).

Historical data are also very useful in defining the volume of the lava erupted during the effusive phase of the eruption, which lasted for at least 3 months until April 1914. Omori (1916) and Koto (1916) made an estimation of the areal extent 
of the lava flows from the two fissure systems, both on land and under the sea and of the related average thicknesses. The two authors calculated a bulk volume for the lava flows of $1.56 \mathrm{~km}^{3}$ (Omori 1916) and $1.02 \mathrm{~km}^{3}$ (Koto 1916). This is nearly one order of magnitude higher than the range of DRE volume estimated for the tephra deposit. Considering that the lava flow had ceased flowing after about 3 months of activity and assuming a lava density of about $2200 \mathrm{~kg} \mathrm{~m}^{-3}$ (Omori 1916), a mass eruption rate between $2.6 \times 10^{5}$ and $4.4 \times 10^{5} \mathrm{~kg} \mathrm{~s}^{-1}$ can be estimated for the effusive phase of the eruption, corresponding to a mean output rate ranging between 100 and $170 \mathrm{~m}^{3} \mathrm{~s}^{-1}$. Such high values have been recorded only for few effusive eruptions from central vents and are comparable to high-intensity basaltic effusive eruptions like the 1950 and 1984 eruptions of Mauna Loa (e.g., Walker 1973b; Riker et al. 2009; Cashman and Mangan 2014), the 2007 eruption of Piton de la Fournaise (Staudacher et al. 2009), or the large lateral 1669 eruption of Monti Rossi at Etna (Branca et al. 2013). Conversely, the estimated output rate is three to four times larger than those recorded for similar mildly evolved lava flows such as those erupted at Hekla in 1991 (Gudmundsson et al. 1992) or the 1946 basaltic andesite lava of Sakurajima (Walker 1973b) and also of more evolved, rhyolitic lava flows as during the Cordón Caulle 2011 eruption (Tuffen et al. 2013).

\section{Ash dispersal}

The shape of the isopach map and the inversion of data on largest suggest that the eruptive plume was dispersed by westerly winds with speed at the tropopause around $40 \mathrm{~m} \mathrm{~s}^{-1}$. Based on the linear wind speed gradient in the troposphere assumed in the model of Carey and Sparks (1986), this corresponds to an average value of the wind speed of $20 \mathrm{~m} \mathrm{~s}^{-1}$. Conversely, from the map of ash arrival times compiled on the basis of Omori's data (Fig. 2), an average velocity of downwind plume transport of about $9 \mathrm{~m} \mathrm{~s}^{-1}$ can be estimated. The large difference between the two values can be related to several causes, such as the offaxis location of the sites (Fig. 2) at which "first deposition times" were reported, a different wind speed gradient with respect to the linear gradient assumed in the model of Carey and Sparks (1986), which could result in a lower average wind speed, or variations in the wind speed (in terms of both intensity and direction) with distance from the vent.

\section{Grain size variations}

All analyzed samples are characterized by polymodal grain size distributions that were deconvolved into the sum of multiple Gaussian subpopulations. Overall, the modal values of the two coarser subpopulations (SP1 and SP2) show a clear decrease with distance from vent. The theoretical distance at which the two subpopulations merge one into the other can be estimated at $64 \mathrm{~km}$ from the vent, although beyond $30 \mathrm{~km}$
SP1 is no more clearly visible (Fig. 10a). This suggests that the presence of these two subpopulations is strongly controlled by the dispersal process and that in order to reconstruct the original grain size distribution of the erupting mixture the information conveyed by samples from the proximal area is of primary importance. Conversely, the finer-grained subpopulation SP3 is characterized by a nearly constant value of $\operatorname{Md} \phi$ and of its relative abundance in each sample, suggesting that it was controlled by a depositional process not variable with distance. The ubiquitous presence of a fine subpopulation with a constant grain size distribution from proximal to distal areas has been observed in all the following cases:

- Soufrière Hills, Montserrat, West Indies (Bonadonna et al. 2002)

- 1979 Soufrière of St Vincent, West Indies (Brazier et al. 1982)

- 1982 El Chichon, Mexico (Varekamp et al. 1984)

- May 18, 1980 Mt. St Helens eruption (Brazier et al. 1983)

- Minoan eruption of Santorini, Greece (Sparks et al. 1983)

- 2008 Chaiten, Chile (Durant et al. 2012)

- 1992 Crater Peak, Alaska (Durant and Rose 2009)

- The recent 2011 Cordón Caulle eruption, Chile (Bonadonna et al. 2015b)

The presence of this invariant subpopulation in all these tephra deposits has been alternatively interpreted as the result of contamination from co-ignimbrite clouds or as the result of aggregation of the fine material. The absence in the Taisho eruption of volumetrically large pyroclastic flow deposits suggests that the SP3 subpopulation possibly records aggregation in the eruptive plume.

\section{Conclusions}

The reconstruction of the explosive phase of the Taisho eruption, based on contemporary chronicles and the reinterpretation of the tephra deposits, depicts an eruptive scenario in which precursory activity preceded the eruption onset by only a few days and was mainly related to seismic activity that increased rapidly toward the eruption. The eruption was also preceded by a general uplift of the area beginning at least 20 years prior to the onset of explosive activity on 11 January 1914 (Hickey et al. 2016), which progressively recovered following the explosive and the effusive phases of the eruption. After the opening of two main fissures on the ESE and WNW flanks of the volcano, the eruption rapidly escalated into its climactic phase (in terms of plume height and mass discharge rate), peaking at a MDR of about $3.6 \times 10^{7} \mathrm{~kg} \mathrm{~s}^{-1}$ around $13 \mathrm{~h}$ after the eruption onset. Considering the substantial discrepancy between the value of MDR derived with the method of Mastin et al., 2009 and with that of Degruyter and Bonadonna 
(2012), and the scale parameter for the quantification of the effect of plume rise height (i.e., $\Pi=0.18$ ), we conclude that the wind advection had a significant effect on the dynamics of the Taisho plume. The observed changes in componentry, with a progressive increase in the amount of the lithic fragments vertically along the sequence, possibly record a continuous conduit-vent system enlargement toward the end of the climatic phase. Tephra dispersal was mainly directed toward the east over a very wide area, with ash falling as far as Bonin (Ogasawara) Islands, about $1200 \mathrm{~km}$ southeast of the volcano, and across Kyushu, Shikoku, and part of Honshu islands, northeast of Sakurajima (Omori, 1916).

Activity waned after about $35 \mathrm{~h}$ of intense emission and was followed by a prolonged phase dominated by effusive activity, accompanied in the first days (at least until January 19,1914 ) by the production of (possibly) sustained ash plumes dispersing ash over a more restricted area around the volcano. Minor discrete Vulcanian explosions, only launching ballistic material around the vents and forming low-level, poorly dispersed ash plumes, accompanied the final stages of the effusive eruption which went on for some months. The deposits of the ash phase (Unit T4) are only clearly recognizable in the southeast direction, where they are found on top of the T1-T3 pumice-bearing sequence. Outside the dispersal fan of these Units, T4 ash deposit possibly mixed with the soil soon after the eruption, and thus we expect that it cannot now be recognized.

The detailed isopach maps (Figs. SM2 and SM3) of the whole tephra deposits of the eruption compiled by Omori (1916) and Koto (1916), when compared with our isopach map of the pumice-bearing deposit (Fig. 6a), clearly suggest that the distribution of the products of the ash emission activity was nearly radial with respect to the volcano, possibly reflecting the dispersal of the ash under variable tropospheric wind conditions, a case typical of prolonged activity. These deposits were rapidly eroded and/or mixed with the soil. Similarly, the products of the minor Vulcanian activity that accompanied the lava effusion are no longer distinguishable in the field.

The estimated volume of the tephra deposit ( 0.25 to $0.45 \mathrm{~km}^{3}$; Table 2) is smaller with respect to the estimate of $0.5 \mathrm{~km}^{3}$ reported in Kobayashi et al. (2013), these values being even smaller than those estimated by integrating the thickness data of Omori (1916) and Koto (1916). We suggest that the larger volumes derived from historical data result from the concurrent effect of mapping the deposits of the entire eruption (subPlinian phase and ash emission phase) and of the higher values of thickness (with respect to the presently measurable deposits) collected immediately after the eruption, a difference which can be explained by post-depositional compaction aided by the presence of vegetation.
Lava flow activity dominated, in terms of erupted volume. Estimated mean output rates place the eruption at the higher end for central effusive eruptions. The association of such intense effusive activity (accompanied by ash emission) following an explosive Plinian-to-subPlinian phase in a same eruptive event is a feature of many complex eruptions (Cioni et al. 2015), and the eruptive scenario reconstructed for the 1914 Taisho eruption for Sakurajima can be considered typical for this type of events.

This study, by providing a detailed stratigraphic reconstruction of the Taisho tephra deposits and a detailed wide dataset of the main physical parameters of the eruption, provides a case-type for mixed, subPlinian explosive-effusive eruptions. Because such eruptions are not unusual at Sakurajima volcano, the data and analysis presented here provide crucial information for a better understanding of the dynamics of such activity and for building risk and hazard scenarios, as completed using these data by Biass et al. (2017). Preliminary comparison of field data and chronicle accounts of the Taisho eruption with the similar data available for the preceding two pumice-bearing eruptions of Bunmei (1471$1476 \mathrm{AD})$ and Anei (1779-1782 AD) point to the occurrence of a similar eruptive scenario for all the three events. This event-type is so taken as a reference for the hazard assessment and emergency planning for a next, high-intensity eruption at Sakurajima volcano as detailed in Biass et al. (2017).

Acknowledgments A. Todde was partially supported by the University of Florence funds for internationalization. R. Cioni and M. Pistolesi were supported by the Italian Civil Protection in the framework of the DEVNET project granted to M. Ripepe. C. Bonadonna was supported by the FN grant no. 200021_156255. The authors are grateful to $\mathrm{M}$. Ripepe, S. Biass, T. Miwa, T. Nishizawa, and P. Gabellini for discussion and assistance in the field, to $\mathrm{M}$. Bagheri for discussion on the determination of the largest clasts, and to L. Dominguez for her help in laser grain size analyses. We are deeply indebted with Associate Editor Judy Fierstein and two anonymous reviewers for their accurate and propositive comments and suggestions.

\section{References}

Abe K (1979) Magnitude of major volcanic earthquakes of Japan 19011925. J Fac Sci Hokkaido Univ 6:201-212

Alfano F, Bonadonna C, Volentik ACM, Connor CB, Watt SFL, Pyle DM, Connor L (2011) Tephra stratigraphy and eruptive volume of the May, 2008, Chaitén eruption, Chile. Bull Volcanol 73:613-630

Bagheri G, Bonadonna C (2016) Aerodynamics of volcanic particles: characterization of size, shape, and settling velocity. In: Mackie $S$ et al. (eds) Volcanic ash, 1st edn. Elsevier, ISBN: 9780081004050 , pp 300

Bagheri GH, Bonadonna C, Manzella I, Vonlanthen P (2014) On the characterization of size and shape of irregular particles. Powder Technol 270:141-115

Biass S., Bagheri G., Bonadonna C. (2015) A Matlab implementation of the Carey and Sparks (1986) model, https://vhub.org/resources/3922

Biass S, Todde A, Cioni R, Pistolesi M, Geshi N, Bonadonna C (2017) Potential impacts of tephra fallout from a large-scale explosive 
eruption at Sakurajima volcano, Japan. Bull Volcanol. https://doi. org/10.1007/s00445-017-1153-5

Blong R, Enright NJ (2011) Preservation of thin tephras. Unpublished manuscript, http://researchrepository.murdoch.edu.au/5785

Bonadonna C, Costa A (2012) Estimating the volume of tephra deposits: a new simple strategy, Geology. https://doi.org/10.1130/G32769.1

Bonadonna C, Costa A (2013) Plume height, volume and classification of volcanic eruptions based on the Weibull function. Bull Volcanol 75:742

Bonadonna C, Houghton BF (2005) Total grain-size distribution and volume of tephra-fall deposits. Bull Volcanol 67:441-456

Bonadonna C, Mayberry GC, Calder ES, Sparks RSJ, Choux C, Jackson P, Lejeune AM, Loughlin SC, Norton GE, Rose WI, Ryan G, Young SR (2002) Tephra fallout in the eruption of Soufrière Hills Volcano, Montserrat. Geological Society, London, Memoirs 21:483-516

Bonadonna C, Cioni R, Pistolesi M, Connor C, Scollo S, Pioli L, Rosi M (2013) Determination of the largest clast sizes of tephra deposits for the characterization of explosive eruptions: a study of the IAVCEI commission on tephra hazard modelling. Bull Volcanol 75:680. https://doi.org/10.1007/s00445-012-0680-3

Bonadonna C, Biass S, Costa A (2015a) Physical characterization of explosive volcanic eruptions based on tephra deposits: propagation of uncertainties and sensitivity analysis. J Volcanol Geotherm Res 296:80-100

Bonadonna C, Cioni R, Pistolesi M, Elissondo M, Baumann V (2015b) Sedimentation of long-lasting wind-affected volcanic plumes: the example of the 2011 rhyolitic Cordón Caulle eruption, Chile. Bull Volcanol 77:13

Bonadonna C, Pistolesi M, Cioni R, Degruyter W, Elissondo M, Baumann V (2015c) Dynamics of wind-affected volcanic plumes: the example of the 2011 Cordón Caulle eruption, Chile. J Geophys Res: Solid Earth. https://doi.org/10.1002/2014JB011478

Bonadonna C, Cioni R, Costa A, Druitt T, Phillips JC, Pioli L, Andronico D, Harris A, Scollo S, Bachmann O, Bagheri G, Biass S, Brogi F, Cashman K, Dominguez L, Dürig T, Galland O, Giordano G, Gudmundsson M, Hort M, Höskuldsson A, Houghton B, Komorowski JC, Küppers U, Lacanna G, Le Pennec JL, Macedonio G, Manga M, Manzella I, de M, Vitturi M, Neri A, Pistolesi M, Polacci M, Ripepe M, Rossi E, Scheu B, Sulpizio R, Tripoli B, Valade S, Valentine G, Vidal C, Wallenstein N (2016) MeMoVolc report on classification and dynamics of volcanic explosive eruptions. Forum Contribution, Bulletin of Volcanology 78:84. https://doi.org/10.1007/s00445-016-1071-y

Branca S, De Beni E, Proietti C (2013) The large and destructive 1669 $\mathrm{AD}$ eruption at Etna volcano: reconstruction of the lava flow field evolution and effusion rate trend. Bull Volcanol 75:694

Brazier S, Davis AN, Sigurdsson H, Sparks RSJ (1982) Fall-out and deposition of volcanic ash during the 1979 explosive eruption of the soufriere of St. Vincent. Journal of Volcanology and Geothermal Research, Volume 14:335-359

Brazier S, Sparks RSJ, Carey SN, Sigurdsson H, Westgate JA (1983) Bimodal grain size distribution and secondary thickening in air-fall ash layers. Nature 301:115-119. https://doi.org/10.1038/301115a0

Carey SN, Sparks RSJ (1986) Quantitative models of the fallout and dispersal of tephra from volcanic eruption columns. Bull Volcanol 48:109-125

Carey S, Bursik M (2015) Volcanic Plumes. In: Sigurdsson H et al. (eds) Encyclopedia of Volcanoes - Second Edition. Academic Press, San Diego, pp 571-585

Cashman KV, Mangan MT (2014) A century of studying effusive eruptions in Hawai' $i$. In Characteristics of Hawaiian volcanoes, M. P. Poland, T. J. Takahashi and C. M. Landowski. U.S. Geol Surv Prof Pap 1801:357-394

Cioni R, Bertagnini A, Santacroce R, Andronico D (2008) Explosive activity and eruption scenarios at Somma-Vesuvius (Italy): towards a new classification scheme. J Volcanol Geotherm Res 178(3):331-346
Cioni R., Pistolesi M., and Rosi M. (2015) Plinian and subplinian eruptions. In: Encyclopedia of volcanoes, Sigurdsson H. ed., 519-535

Degruyter W, Bonadonna C (2012) Improving on mass flow rate estimates of volcanic eruptions. Geophys Res Lett. https://doi.org/10. 1029/2012GL052566

Durant AJ, Rose WI (2009) Sedimentological constraints on hydrometeor-enhanced particle deposition: 1992 Eruptions of Crater Peak, Alaska. Journal of Volcanology and Geothermal Research, Volume 186:40-59

Durant AJ, Villarosa G, Rose WI, Delmelle P, Prata AJ, Viramonte JG (2012) Long-range volcanic ash transport and fallout during the 2008 eruption of Chaitén volcano, Chile. Physics and Chemistry of the Earth, Volumes 45-46:50-64

Engwell SL, Sparks RSJ, Aspinall WP (2013) Quantifying uncertainties in the measurement of tephra fall thickness. J Appl Volcanol 2(5)

Fierstein J, Nathenson M (1992) Another look at the calculation of fallout tephra volumes. Bull Volcanol 54:156-167

Geshi N, Miyabuchi Y (2016) Conduit enlargement during the precursory Plinian eruption of Aira Caldera, Japan. Bull Volcanol 78:63. https:// doi.org/10.1007/s00445-016-1057-9

Gonnermann H M, Manga M (2013) Dynamics of magma ascent in the volcanic conduit. In: Fagents SA, Gregg TKP, Lopes RMC (eds) Modeling volcanic processes: the physics and mathematics of volcanism, pp 55-84. https://doi.org/10.1017/CBO9781139021562. 004

Gudmundsson A, Oskarsson N, Gronvold K, Saemundsson K, Sigurdsson O, Stefansson R, Gislason SR, Einarsson P, Brandsdottir B, Larsen G, Johannesson H, Thordarsson T (1992) The 1991 eruption of Hekla, Iceland. Bull Volcanol:238-246

Hickey J, Gottsmann J, Nakamichi H, Iguchi M (2016) Thermomechanical controls on magma supply and volcanic deformation: application to Aira caldera, Japan. Sci Rep 6:32691. https:// doi.org/10.1038/srep32691

Hildreth W, Drake RE (1992) Volcán Quizapu, Chilean Andes. Bull Volcanol 54:93-125

Houghton BF, Wilson CJN (1989) A vesicularity index for pyroclastic deposits. Bull Volcanol 51:451-462

Imura R (1998) Reconstruction of the sequence of the Anei eruption of Sakurajima volcano (A.D. 1779-1782) using the historical records. Bull. Volcanol. Soc Japan 43:373-383

Inman DL (1952) Measures for describing the size distribution of sediments. J Sediment Petrol 22:125-145

Ishihara T, Takayama T, Tanaka Y, Hirabayashi J (1981) Lava flows at Sakurajima volcano (I) - volume of the historical lava flows. Annuals of Disas Prev Res Inst, Kyoto Univ, 24B-1:1-10

Kobayashi T, Miki D, Sasaki H, Iguchi M, Yamamoto T, Uto K (2013) Geological map of Sakurajima Volcano, Second edn. Geological Survey of Japan, Tsukuba

Koto B (1916) The great eruption of Sakura-jima in 1914. J Coll Sci Imperial Univ Tokyo 38:1-237

Krumbein WC (1941) Measurement and geological significance of shape and roundness of sedimentary particles. J Sediment Res 11:64-72

Kudo T, Hoshizumi H (2006) P-130 evaluation of volcanic activity during the last 10,000 years in the Tohoku District, Northeast Japan: Application of the AIST database "Catalog of Eruptive Events during the last 10,000 years in Japan". The Geological Society of Japan. http://ci.nii.ac.jp/naid/110006199075/en/

Larsen G, Eiríksson J (2008) Late quaternary terrestrial tephrochronology of Iceland - frequency of explosive eruptions, type and volume of tephra deposits. J Quaternary Sci 23:109-120

Machida H (2002) Volcanoes and tephras in the Japan area. Glob Environ Res 6:19-28

Mason BG, Pyle DM, Oppenheimer C (2004) The size and frequency of the largest explosive eruptions on Earth. Bull Volcanol 66(8):735-748

Mastin LG, Guffanti M, Servranckx R, Webley P, Barsotti S, Dean K, Durant A, Ewert JW, Neri A, Rose WI, Schneider D, Siebert L, 
Stunder B, Swanson G, Tupper A, Volentik A, Waythomas CF (2009) A multidisciplinary effort to assign realistic source parameters to models of volcanic ash-cloud transport and dispersion during eruptions. J Volcanol Geotherm Res. https://doi.org/10.1016/j. jvolgeores.2009.01.008

Miwa T, Geshi N, Shinohara H (2013) Temporal variation in volcanic ash texture during a vulcanian eruption at the Sakurajima volcano, Japan. J Volcanol Geotherm Res 260:80-89

Nagaoka S (1988) Late Quaternary tephra layers from the caldera volcanoes in and around Kagoshima bay, southern Kyushu. Japan. Geogr. Rep, Tokyo Metropolitan Univ. 23:49-122

Nakamura K (2006) Textures of plagioclase microlite and vesicles within volcanic products of the 1914-1915 eruption of Sakurajima Volcano, Kyushu, Japan. J Mineral Petrol Sci 101:178-198

Omori F (1916) The Sakura-Jima eruption and earthquakes. Bulletin of The Imperial Earthquake Investigation Committee, pp 525

Pistolesi M, Cioni R, Bonadonna C, Elissondo M, Baumann V, Bertagnini A, Chiari L, Gonzales R, Rosi M, Francalanci L (2015) Complex dynamics of small-moderate volcanic events: the example of the 2011 rhyolitic Cordón Caulle eruption, Chile. Bull Volcanol 77:1-24

Pyle DM (1989) The thickness, volume and grain size of tephra fall deposits. Bull Volcanol 51(1):1-15

Pyle DM (2015) Sizes of volcanic eruptions. Encyclopedia of Volcanoes: 257-264

Riker JM, Cashman KV, Kauahikaua JP, Montierth CM (2009) The length of channelized lava flows: insight from the 1859 eruption of Mauna Loa Volcano, Hawaii. J Volcanol Geotherm Res 183(3): $139-156$

Rittmann A (1962) Volcanoes and their activity. Interscience (Wiley), New York, pp 305

Simkin T, Siebert L (2000) Earth's volcanoes and eruptions: an overview. In: Sigurdsson H, Houghton BF, McNutt SR, Rymer H, Stix J (eds) Encyclopedia of volcanoes. Academic Press, San Diego, pp 249-269

Sparks RSJ, Brazier S, Huang TC, Muerdter D (1983) Sedimentology of the Minoan deep-sea tephra layer in the Aegean and Eastern Mediterranean. Marine Geology Volume 54:131-167

Staudacher T, Ferrazzini V, Peltier A, Kowalski P, Boissier P, Catherine P, Lauret F, Massin F (2009) The April 2007 eruption and the
Dolomieu crater collapse, two major events at Piton de la Fournaise. J Volcanol Geotherm Res 184(1-2):126-137

Takahashi M, Otsuka T, Sako H, Kawamata H, Yasui M, Kanamaru T, Otsuki M, Kobayash T, Ishihara K, Miki D (2013) Temporal variation for magmatic chemistry of the Sakurajima volcano and Aira Caldera region, Southern Kyushu, Southwest Japan since 61 ka and its implications for the evolution of magma chamber system. Bull Volcanol Soc Japan 58(1):19-42

Thorarinsson S (1954) The eruption of Hekla 1947-1948. Soc Sci. Islandica, Reykjavik, pp 1-23.

Tuffen H, James MR, Castro JM, Schipper C (2013) Exceptional mobility of an advancing rhyolitic obsidian flow at Cordón Caulle volcano in Chile. Nat Commun 4:1-7

Varekamp JC, Luhr JF, Prestegaard KL (1984) The 1982 eruptions of El Chichón Volcano (Chiapas, Mexico): character of the eruptions, ashfall deposits, and gas phase. J Volcanol Geotherm Res 23(1-2):39-68

Walker GPL (1973a) Explosive volcanic eruptions - a new classification scheme. Geol. Rundsch 62:431-446 4,6,9

Walker GPL (1973b) Lengths of lava flows. Philos Trans: Math Phys Eng Sci 274:107-118

Walker GPL (1981) Plinian eruptions and their products. Bull Volcanol 44(3):223

Wilson L, Sparks RSJ, Walker GPL (1980) Explosive volcanic eruptions - IV. The control of magma properties and conduit geometry on eruption column behaviour. Geophys J Int 63(1):117-148

Wohletz KH, Sheridan MF, Brown WK (1989) Particle-size distributions and the sequential fragmentation/transport theory applied to volcanic ash. J Geophys Res Solid Earth Planets 94(B11):15703-15721

Woods AW (1995) The dynamics of explosive volcanic eruptions. Rev Geophys 33(4):495-530

Yasui M, Takahashi M, Ishihara K, Miki D (2006) Records on the 19141915 eruption of Sakurajima volcano, Japan. Proc. Inst Natural Sci Nihon Univ 41:75-107

Yasui M, Takahashi M, Ishihara K, Miki D (2007) Eruptive style and its temporal variation through the 1914-1915 eruption of Sakurajima volcano southern Kyushu Japan. Bull.Volcanol. Soc. Japan 52:161-186 